\title{
EFEITO DO FITOPLASMA DO ENFEZAMENTO DO MILHO E DA POPULAÇÃO DE VETORES INFECTIVOS SOBRE OS SINTOMAS E COMPONENTES DE PRODUÇÃO
}

\section{Claudia Maria TOFfanelli}

Engenheiro Agrônomo

Orientador: Prof. Dr. IVAN PAULO BEDENDO

\begin{abstract}
Dissertação apresentada à Escola Superior de Agricultura "Luiz de Queiroz", Universidade de São Paulo, para obtenção do título de Mestre em Agronomia, Área de Concentração: Fitopatologia.
\end{abstract}

P I R A C I C A B A

Estado de São Paulo - Brasil

Março - 2001 


\section{Dados Internacionais de Catalogação na Publicaçäo (CIP) DIVISAO DE BIBLIOTECA E DOCUMENTAÇAO - Campus "Luiz de Queiroz"/USP}

\section{Toffanelli, Claudia Maria}

Efeito do fitoplasma do enfezamento do milho e da populaçăo de vetores infectivos sobre os sintomas e componentes da produção / Claudia Maria Toffanelli. - - Piracicaba, 2001.

$68 \mathrm{p.}$

Dissertação (mestrado) - Escola Superior de Agricultura Luiz de Queiroz, 2001. Bibliografia.

1. Enfezamento-do-milho 2. Fitopatologia 3. Fitoplasma 4. Milho híbrido 5. Relação patógeno-vetor-hospedeiro I. Título

CDD 633.15

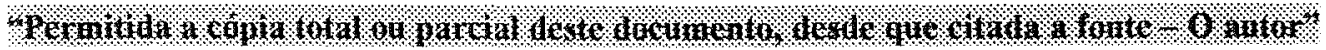


Aos pais Etio e Odila que me deram a vida e me ensinaram a vivê-la com dignidade, dedico minha conquista com a mais profunda gratidão; aos irmãos Lourdes, Luis, Sônia e Fábio, por todo carinho e incentivo proporcionados durante minha vida; ao Bruno, pelo carinho e afeto partilhados, ofereço 


\section{AGRADECIMENTOS}

A autora expressa seus agradecimentos às seguintes instituições e pessoas que colaboraram para a execuçāo do presente trabalho:

À Escola Superior de Agricultura "Luiz de Queiroz", Departamento de Fitopatologia, pela oportunidade de realização do curso;

À Coordenação de Aperfeiçoamento de Pessoal de Nivel Superior, pela concessão da bolsa de estudos;

Ao professor Dr. Ivan Paulo Bedendo, pela orientação, amizade, apoio e incentivo em todos os momentos;

Ao professor Dr. João Roberto Spotti Lopes e ao Eng. Agr. Charles Martins de Oliveira (Setor de Entomologia - ESALQ) pelas valiosas contribuições e pela extrema disposição em auxiliar;

Ao professor Jorge A.M. Rezende pelas facilidades concedidas para a execução do teste ELISA. Ao professor Tasso Leo Krugner, pela revisão do Summary;

Aos demais professores do Departamento de Fitopatologia da ESALQ, pela amizade e ensinamentos transmitidos;

Aos funcionários do Departamento de Fitopatologia Heloísa, Marise, Rodolfo, Edivaldo e Pedro, pela amizade e presteza no auxilio solicitado;

À professora Dra. Glaucia de Figueiredo Nachtigal, pela amizade e iniciação na área de Fitopatologia;

Aos professores Dr. Décio Barbin, Dra. Sônia Piedade (Departamento de Matemática e Estatística - ESALQ) e Dr. Gener Pereira (Departamento de Ciências Exatas - FCAV/UNESP) pela assistência nas análises estatísticas; 
Ả bibliotecária Eliana Maria Garcia Sabino, pelas correçōes das referências bibliográficas;

Às amigas, Rosangela Cristina Marucci e Marina Regina Frizzas, pela amizade, companheirismo e apoio constante;

À Eng. Agr. Luciana Bianchini pelo espírito solícito e indispensável auxilio durante todas as etapas de desenvolvimento deste trabalho;

Aos demais amigos conquistados, pelos bons momentos partilhados. 


\section{SUMÁRIO}

Página

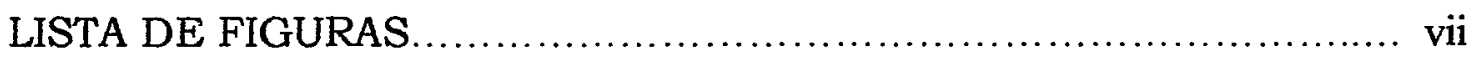

LISTA DE TABELAS ....................................................... vii

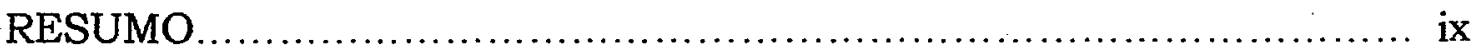

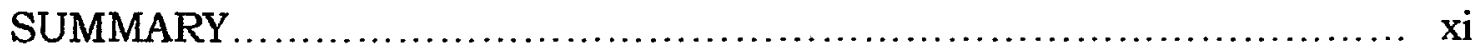

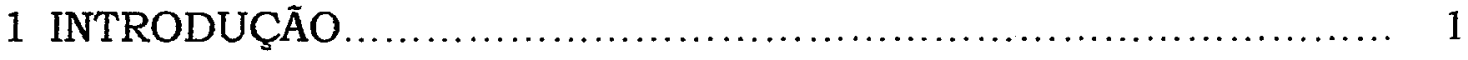

2 REVISÃO DE LITERATURA ............................................ 3

2.1 Enfezamento vermelho........................................... 3

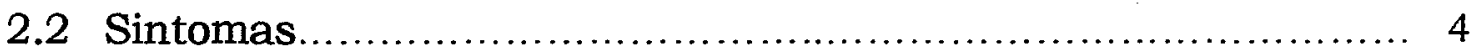

2.3 Etiologia .......................................................... 5

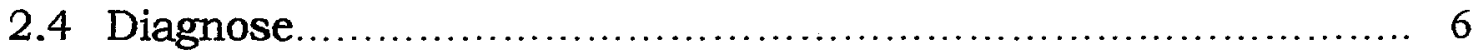

2.5 Transmissão......................................................... 7

2.6 Danos................................................................ 9

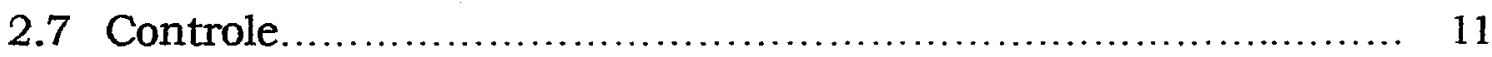

3 EFEITO DA POPULAÇÃO INFECTIVA DE Dalbulus maidis SOBRE

A PRODUÇÃO DE GRÃOS E O DESENVOLVIMENTO DE

SINTOMAS ASSOCIADOS AO FITOPLASMA DO ENFEZAMENTO VERMELHO DO MILHO ............................................. 13

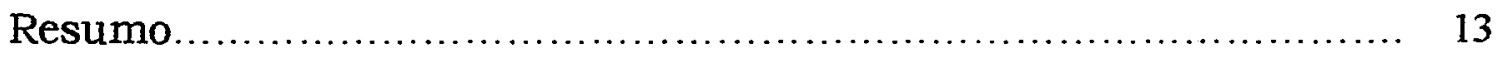

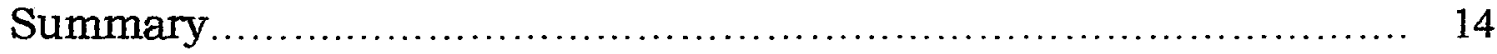

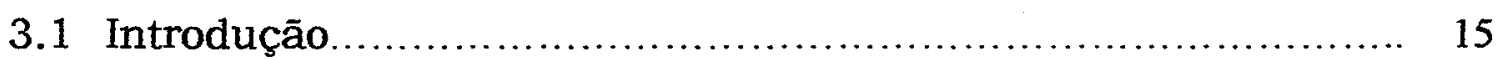

3.2 Material e métodos.............................................. 16

3.2.1 Instalação do ensaio ....................................... 16

3.2.2 Avaliação do ensaio.............................................. 18

3.2.2.1 Sintomatologia e produção de grãos .......................... 18

3.2.2.2Teste de retenção de grãos em peneiras........................ 18

3.2.2.3 Teste de germinação de sementes............................. 19 
3.2.2.4Testes de PCR e ELISA ......................................... 19

3.2.3 Análise estatística.............................................. 20

3.3 Resultados........................................................... 21

3.3.1 Desenvolvimento de sintomas................................ 21

3.3.2 Incidência da doença........................................ 23

3.3.3 Altura de plantas e produção de grãos .......................... 23

3.3.4 Componentes de produção...................................... 25

3.3.5 Teste de retenção de grãos em peneiras........................... 30

3.3.6 Teste de germinação de sementes............................. 31

3.3.7 Testes de PCR e ELISA............................................ 31

3.4 Discussāo........................................................... 32

4 EFEITO DA INOCULAÇÃO DO FITOPLASMA DO ENFEZAMENTO SOBRE O DESENVOLVIMENTO E PRODUÇĀO DE HÍBRIDOS DE

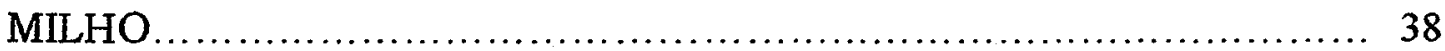

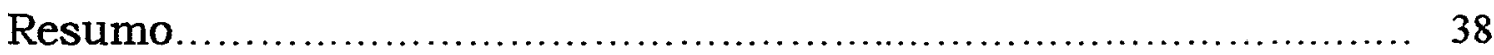

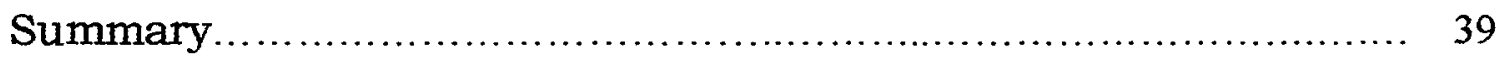

4.1 Introduçāo ........................................................... 40

4.2 Material e métodos ................................................ 41

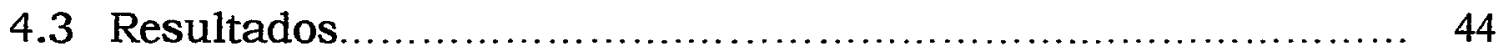

4.3.1 Desenvolvimento de sintomas................................ 44

4.3.2 Danos causados pelo enfezamento vermelho................... 47

4.3.3 Teste de retenção de grãos em peneiras ......................... 51

4.3.4 Teste de germinação de sementes............................. 51

4.3.5 Testes de PCR e ELISA........................................... 51

4.4 Discussão............................................................ 53

5 CONCLUSÕES ........................................................ 57

REFERÊNCIAS BIBLIOGRÁFICAS..................................... 58 


\section{LISTA DE FIGURAS}

Página

1 Efeito da população infectiva de $D$. maidis sobre as espigas de plantas de milho, híbrido XLX 520, inoculadas com fitoplasma do enfezamento......................................

2 Efeito da população infectiva de $D$. maidis sobre a altura e os componentes de produção de plantas de milho inoculadas com o fitoplasma do enfezamento

3 Efeito da populaçāo infectiva $D$. maidis sobre o tamanho de grãos, avaliado através de um conjunto de peneiras de malhas circulares, produzidos por plantas de milho inoculadas com o fitoplasma do enfezamento.

4 Sintomas mostrados por plantas, de diferentes hibridos, inoculadas com o fitoplasma do enfezamento através de dez insetos infectivos/planta. A) avermelhamento foliar $e$ brotações axilares; B) estrias de coloração vermelha e parda..

5 Efeito da infecção do fitoplasma do enfezamento sobre o tamanho de grãos de híbridos comerciais, avaliado através de um conjunto de peneiras de malhas circulares de 7.14 a $9.52 \mathrm{~mm}$. 


\section{LISTA DE TABELAS}

Página

1 Incidência do enfezamento vermelho, altura de plantas e produção de grãos por plantas do hibrido XLX 520, não submetidas à alimentação de insetos (testemunha), submetidas a insetos sadios e inoculadas com insetos infectivos

2. Efeito da população infectiva de $D$. maidis sobre os componentes de produçāo de plantas do híbrido XLX 520, inoculadas com fitoplasma do enfezamento vermelho.

3 Efeito do fitoplasma do enfezamento vermelho sobre a altura e produção de grãos por plantas de milho, de diferentes hibridos, inoculadas através de $\mathrm{dez}$ insetos infectivos/planta

4 Efeito do fitoplasma do enfezamento vermelho sobre o número e tamanho de espigas produzidas por plantas de milho, de diferentes híbridos, inoculadas através de dez insetos infectivos/planta 


\title{
EFEITO DO FITOPLASMA DO ENFEZAMENTO DO MILHO E DA POPULAÇÃO DE VETORES INFECTIVOS SOBRE OS SINTOMAS E COMPONENTES DE PRODUÇÃO
}

\author{
Autora: CLAUDIA MARIA TOFFANELLI \\ Orientador: Prof. Dr. IVAN PAULO BEDENDO
}

\section{RESUMO}

O enfezamento vermelho do milho, associado a um fitoplasma, é uma doença de expressiva importância econômica para a cultura, sendo disseminada através da cigarrinha do milho Dalbulus maidis (DeLong \& Wolcott). Recentemente, altas incidências da doença, resultando em sérios prejuizos, foram registradas nas regiões produtoras, principalmente no sudeste e centro-oeste do Brasil, onde se realizam plantios tardios e consecutivos de milho. Em condições de campo, o enfezamento vermelho normalmente ocorre associado ao enfezamento pálido, causado por espiroplasma, formando um complexo de doenças, uma vez que ambos agentes são transmissiveis pelo mesmo vetor. No presente trabalho, foi investigado o efeito isolado do fitoplasma sobre a sintomatologia e a produção de dez híbridos de milho, bem como o efeito da população infectiva do vetor sobre o desenvolvimento de sintomas e as alteraçōes sobre os componentes de produção da planta de milho. Para isto, plantas do hibrido XLX 520 foram experimentalmente inoculadas com fitoplasma por meio de $1,3,6$ e 9 insetos infectivos/planta. Numa segunda etapa, os hibridos XLX 520, Z 8452, C 909, P 3063, P 3081, AG 3010, FT 9006, FT 9043, DO 02 e D 766 foram inoculados por meio de 10 insetos infectivos/planta. Os ensaios foram conduzidos sob condições de telado no periodo de 
setembro/1999 a abril/2000. Os resultados obtidos revelaram que a incidência da doença, resultando em severas perdas, foi proporcionalmente maior à medida em que se elevou o número de insetos infectivos/planta. Maiores freqūências de grãos miúdos, espigas pequenas, número reduzido de fileiras e de grãos, foram verificados para os niveis mais altos de infestação. A germinação de sementes foi afetada negativamente em função da densidade da população infectiva. Os resultados obtidos na inoculação de híbridos revelaram o aparecimento de sintomas típicos de avermelhamento, proliferação de espigas e enfezamento de plantas, em graus variados em função dos híbridos utilizados. Para aqueles mais suscetiveis, além da alta proporção de grãos miúdos, foram registradas reduçōes de até $35 \%$ na altura de plantas, $98 \%$ na produção de grãos, $89 \%$ no tamanho de espigas, $50 \%$ no número de fileiras de grãos, $98 \%$ no número de grãos e $18 \%$ na germinação de sementes. Estes resultados confirmaram a importância do enfezamento vermelho para a cultura do milho. 


\section{EFFECT OF MAIZE BUSHY STUNT PHYTOPLASMA AND INFECTIVE VECTORS POPULATION ON SYMPTOMS AND PRODUCTION COMPONENTS}

Author: CLAUDIA MARIA TOFFANELLI Adviser: Prof. Dr. IVAN PAULO BEDENDO

\section{SUMMARY}

Maize bushy stunt, associated to a phytoplasma transmitted by Dalbulus maidis, has an important economic role on corn crop. High incidences have been registered since last decade, resulting in significant losses, mainly in the south and central states of Brazil, where corn is sown lately or cultivated during all the year. In field conditions, maize bushy stunt occurs associated to corn stunt, caused by a spiroplasma, forming a complex, because both pathogens are transmitted by the same vector. This work deals about the single effect of the phytoplasma on the symptomatology and yield of ten hybrids, and about the effect of the vector population on the symptom development and yield components. In the first step, hybrid XLX 520 plants were experimentally inoculated with phytoplasma by 1, 3, 6 and 9 infective insects of $D$. maidis/plant. In the second step, ten hybrids were inoculated by ten infective vectors/plant. Both trials were carried out on a screenhouse, on 1999 and 2000. Results showed that the incidence of the disease was proportional to the number of infective insects/plant. High proportion of small grains and abnormal ears, and reduced number of lines and grains/ear and reduction on seed germination were observed for higher levels of infective vectors. The results in relation to the hybrid trial showed that the symptoms of stunt, leaf reddening and 
ears proliferation occurred in variable levels according to the hybrid. For the most susceptible hybrids, there was a high proportion of small grains and reduction of up to $35 \%$ for plant height, $98 \%$ for grain yield, $89 \%$ for ear size, $50 \%$ for number of lines/ear, $98 \%$ for number of grains and $18 \%$ for seed germination. These results confirmed that maize bushy stunt is a serious disease for corn. 


\section{INTRODUÇÃo}

O enfezamento vermelho é uma doença de relevante importância econômica na cultura do milho (Zea mays L.), distribuida desde o sul dos Estados Unidos até a Argentina (Bedendo, 1999). Associada a um fitoplasma, procarioto sem parede celular e habitante do floema de plantas, a doença é transmitida por meio de insetos do tipo cigarrinhas, destacando-se a espécie Dalbulus maidis (DeLong \& Wolcott) (Hemiptera, Cicadellidae) (Nault, 1980; Power, 1989).

Até recentemente, as doenças do milho associadas a vírus $\mathrm{e}$ Mollicutes transmitidos por $D$. maidis tinham pouca expressão no Brasil (Costa et al., 1971). Entretanto, com a expansão dos plantios tardios e consecutivos e a adoção de irrigação, proporcionando a presença do milho e da cigarrinha no campo durante $o$ ano inteiro, perdas consideráveis da produção têm sido registradas em função dos altos indices de incidência da doença (Folegatti et al., 1997a; Lopes et al., 1997; Oliveira et ai., 1998). Além disso, os danos têm-se mostrado mais acentuados quando a doença incide em híbridos mais suscetiveis e principalmente, quando a infecção ocorre em estádios iniciais de crescimento das plantas (Scott et al., 1977).

Em condiçōes naturais, o enfezamento vermelho faz parte de um complexo formado pelo enfezamento pálido e a risca do milho, constituindo-se num fator limitante à produção do milho na América Latina (Nault, 1990). Os agentes do complexo são transmitidos por $D$. 
maidis, sendo, a caracterização de sintomas e os danos provocados pelos componentes do complexo dificeis de serem avaliados isoladamente em condições de campo.

Relatos sobre o complexo do enfezamento evidenciam a importância atual do enfezamento vermelho para a cultura do milho, uma vez que a doença vem sendo registrada como predominante e mais severa dentro do complexo (Massola Júnior et al., 1998; Oliveira et al., 1998). No entanto, pouco se conhece sobre as características deste patossistema. A relação entre a população do vetor e o desenvolvimento de sintomas e alteração na produção nāo estão consistentemente demonstrados. Estudos que envolvam um maior conhecimento sobre a relação patógeno $\mathrm{x}$ vetor $\mathrm{x}$ hospedeiro são indispensáveis para que se possa obter subsídios para um maior sucesso no controle do enfezamento, através de um programa de manejo adequado das doenças.

Assim, o presente trabalho teve por objetivos:

1) avaliar o efeito da população infectiva de $D$. maidis sobre o desenvolvimento e a produção de plantas de milho;

2) avaliar o efeito do fitoplasma sobre a sintomatologia e a alteração nos componentes de produção de diversos híbridos de milho; 


\section{REVISÃo DE LITERATURA}

\subsection{Enfezamento Vermelho}

A cultura do milho está sujeita a uma série de doenças causadas por fatores bióticos e/ou abióticos (Silva, 1997). Entretanto, com o aumento da área cultivada e a tendência de plantios continuos, a importância relativa de pragas e doenças foi alterada na cultura, tendo o enfezamento vermelho assumido papel importante nos últimos anos (Waquil \& Fernandes, 1992; Waquil et al., 1999).

Em 1955, Maramorosch descreveu dois tipos de enfezamento no México, denominados de enfezamento vermelho e enfezamento pálido, causados por fitoplasma e espiroplasma, respectivamente. A forma vermelha, chamada também de tipo Mesa Central e a pálida, designada como tipo Rio Grande, têm ampla distribuição pelo continente americano, sendo conhecidas no Brasil desde o início da década de 70 , quando foram consideradas de importância secundária, passando desapercebidas pelos produtores (Costa et al., 1971). No entanto, a partir de 1980, em função de plantios sucessivos e tardios na região Centro-Sul, envolvendo Paraná, São Paulo, Mato Grosso, o enfezamento foi aumentando significativamente de importância na cultura do milho (Dudienas et al., 1997; Folegatti et al., 1997a; Oliveira et al., 1998).

O enfezamento vermelho associado ao enfezamento pálido e à risca do milho, causados pelo espiroplasma e virus da risca do milho, 
respectivamente, são doenças limitantes à produção, devido à falta de disponibilidade de híbridos resistentes e à adoção da prática de "safrinha", a qual envolve o plantio tardio do milho (Massola Júnior et al., 1999b; Nault, 1990). No entanto, o enfezamento vermelho assume especial importância em função das altas incidências, como verificadas nos municipios de Barretos (41\%), Guaira (68\%), Uberaba (65.3 a $100 \%$ ), Goiatuba e Vicentinópolis (60\%), Itumbiara (47.5\%). Alta freqüência tem resultado em sérios prejuizos à cultura, o que tem preocupado os produtores de várias regiōes brasileiras (Dudienas et al., 1997; Lopes et al., 1997; Oliveira et al., 1997; Oliveira et al., 1998; Waquil et al., 1997).

\subsection{Sintomas}

As plantas infectadas pelo fitoplasma apresentam clorose nas margens e no ápice das folhas seguido de um avermelhamento. Os bordos podem se apresentar rasgados $\mathrm{e}$ as folhas torcidas e de tamanho reduzido (Balmer \& Pereira, 1987; Nault, 1980; Silva et al., 1991; Tsai \& Falk, 1988). Depois de iniciados, os sintomas evoluem à medida em que a planta emite novas folhas e, simultaneamente, a planta torna-se enfezada (Moya-Raygoza \& Nault, 1998). Podem ser observados tambẻm proliferação de espigas pequenas, grãos miúdos, frouxos, descoloridos, manchados ou chochos, sistema radicular reduzido e perfilhamento na base da planta e nas axilas foliares (Nault, 1980; Oliveira et al., 1998). Plantas afetadas pelo fitoplasma apresentam enfezamento mais severo, quando comparadas com plantas infectadas pelo espiroplasma, agente causal do enfezamento pálido (Bedendo, 1999). 
Massola Júnior et al. (1999c), quantificando os danos causados pelo enfezamento pálido e vermelho do milho em condições de campo, verificaram que plantas infectadas durante a fase vegetativa exibiram os sintomas somente após o florescimento. Em estudos realizados por Scott et al. (1977), plantas infectadas que desenvolveram sintomas precocemente foram mais prejudicadas do que aquelas que os expressaram tardiamente.

Nem todos os hibridos desenvolvem a coloração vermelha quando infectados por este patógeno (Nault, 1980). A redução do porte de planta, formação de perfilhos e proliferação espigas nem sempre foram verificados em plantas infectadas (Costa et al., 1971; Hruska \& Peralta, 1997). O desenvolvimento de sintomas pode ser influenciado por alguns fatores como resistência do hospedeiro, estádio de desenvolvimento e fatores do ambiente (Folegatti et al., 1997a; Madden \& Nault, 1983; Moya-Raygoza \& Nault, 1998; Nault, 1980).

\subsection{Etiologia}

O agente causal do enfezamento vermelho é um fitoplasma, procarioto sem parede celular, pertencente a Classe Mollicutes (Balmer \& Pereira, 1987; Gundersen et al., 1994). Internamente à célula, grânulos densos do tipo ribossomos acham-se distribuídos na periferia $\mathrm{e}$ um material filamentoso ocupa a região central, provavelmente correspondendo ao DNA. A reprodução ocorre por gemulação ou fissão binária transversa tanto no interior do vetor como nos elementos de floema da planta (Davis, 1995; Davis \& Lee, 1991; Kitajima \& Costa, 1972). 
Em plantas afetadas, os fitoplasmas limitam-se ao floema, sendo distribuidos sistemicamente por toda planta, de maneira desuniforme. Em D. maidis localiza-se em vários tecidos e órgãos, como glândulas salivares, túbulos de Malpighi, músculos, epiderme, tecido adiposo, trato intestinal e gânglios (Kitajima \& Costa, 1972).

Além de alguns insetos vetores, a gama de hospedeiros do fitoplasma do enfezamento vermelho restringe-se basicamente ao milho e a três raças de teosinto mexicano Zea mays L. mexicana. $\mathrm{O}$ teosinto perene Zea perennis e Z. diploperennis são hospedeiros diferenciais, sendo ambos suscetiveis ao espiroplasma e não ao fitoplasma (Nault \& DeLong, 1980; Tsai \& Falk, 1988).

\subsection{Diagnose}

A diagnose de doenças associadas aos fitoplasmas é dificultada pelo fato destes organismos não serem cultiváveis em meio de cultura. Assim, o emprego de microscopia eletrônica, métodos imunológicos e técnicas moleculares têm um papel importante na detecção de fitoplasmas em tecidos de plantas sintomáticas, visando confirmar a diagnose feita com base nos sintomas (Chen \& Jiang, 1988; Davis \& Lee, 1991; Kitajima, 1994; Lee et al., 1993).

No entanto, a diagnose acurada de doenças associadas a fitoplasmas por meio de microscopia eletrônica tem sido limitada por vários fatores incluindo a distribuição desuniforme desse microrganismo nas plantas hospedeiras (Davis, 1995). Além disso, o teste ELISA, embora muito sensivel, rápido, barato e relativamente fácil, tem sido pouco utilizado devido dificuldade de obtenção de antissoro (Davis, 1995; Lee \& Davis, 1992 ). 
Nos últimos anos, a detecção de fitoplasmas para fins de diagnose tem sido realizada com metodologias baseadas em análises moleculares (Namba et al., 1993). A técnica de PCR (Polymerase Chain Reaction), rotineiramente empregada em função de sua sensibilidade, tem sido aplicada em vários trabalhos para a detecção do fitoplasma associado ao enfezamento vermelho (Davis, 1995; Harrinson et al., 1996; Lee \& Davis, 1992; Lopes et al., 1997; Oliveira et al., 1995). Além de sua utilidade na detecção e suas implicações na diagnose e epidemiologia, métodos moleculares são úteis na diferenciação e identificação de fitoplasmas, tomando-se por base o DNA (Gundersen et al., 1996; Namba et al., 1993). Nesse sentido, num trabalho clássico, Lee et al. (1998) classificaram os fitoplasmas em 14 grupos distintos e mais 41 subgrupos, empregando as técnicas de PCR e RFLP (Restricion Fragment Length Polymorphism). De acordo com os autores, o fitoplasma do enfezamento vermelho do milho pertence ao grupo $16 \mathrm{~S}$ rDNA-I, subgrupo B dentro de Aster Yellows.

O PCR duplo, onde o fragmento de DNA amplificado por um par de oligonucleotideos e re-amplificado por um segundo par distinto do primeiro, também tem sido empregado como recurso para a detecção de fitoplasma em plantas de milho (Bedendo et al., 2000). A anâlise do fragmento obtido no PCR, usando em seqũência a têcnica de RFLP, permitiu a constatação de que o fitoplasma que ocorre no Brasil é geneticamente similar ao agente do enfezamento vermelho que ocorre nos Estados Unidos, pertencente ao grupo I-B.

\subsection{Transmissão}


Quanto à transmissão do patógeno, várias espécies de cigarrinhas foram relatadas como vetoras, destacando-se Dalbulus maidis, Dalbulus elimatus, Graminiella nigrofons e Baldulus tripsaci (Madden \& Nault, 1983; Nault, 1980). Alguns relatos apontam D. maidis (DeLong \& Wolcott) (Hemiptera: Cicadellidae) o vetor mais eficiente por apresentar alta taxa de transmissão do patógeno, a qual pode variar de 43.9 a $88.9 \%$ (Leagrand \& Power, 1994; Madden \& Nault, 1983). $D$. maidis tem sido referida como a única espécie do gênero Dalbulus encontrada em milho nas regiões Centro-Sul e Nordeste do Brasil (Oliveira, 1996). A cigarrinha, apresentando alta mobilidade e intensa associação com o milho cultivado, é ausente no fim da entressafra (setout) e aparece, subitamente, logo após a germinação do milho (Oliveira et al., 1998; Waquil \& Fernandes, 1992). Segundo Waquil (1997), a densidade populacional flutua ao longo do ano em torno de 1 adulto/planta, ocorrendo um pico populacional nos meses de março/abril, cuja densidade ultrapassa 10 adultos/planta.

A cigarrinha $D$. maidis é capaz de causar sérias perdas na produção e na qualidade da silagem de milho. Quando a população é muito alta, o inseto pode ocasionar seca e morte das plantas jovens, em função da intensa sucção da seiva e da grande quantidade de ovos depositados no limbo foliar ou ainda pela ação tóxica de sua saliva e/ou devido à excreção açucarada que propicia desenvolvimento de fungos sobre as folhas (Bushing \& Burton, 1974; Marin, 1987).

$\mathrm{Na}$ cultura do milho, além de transmitir fitoplasma de maneira persistente e propagativa, D. maidis é vetora de Spiroplasma kunkelii agente do enfezamento pálido e do virus da risca do milho (Moya Raygoza \& Nault, 1998; Nault \& Madden, 1985).

Vârios relatos têm demonstrado a influência da temperatura no comportamento de $D$. maidis e na transmissão do patógeno. Um efeito 
negativo no número de ovos depositados, na viabilidade de ovos e na eclosão de ninfas foi verificado quando plântulas foram incubadas a uma temperatura de 17 a $20^{\circ} \mathrm{C}$ (Waquil et al., 1999). A influência da temperatura também foi constatada na sobrevivência de $D$. maidis, reprodução do fitoplasma, periodo de retenção, periodo de latência, taxa de transmissão, entre outros (Moya-Raygoza \& Nault, 1998; Nault, 1980; Waquil et al., 1999).

A interação entre fitoplasma e vetores foi apresentada por Madden \& Nault (1983). Esses autores obtiveram um aumento da sobrevivência e da taxa de transmissão pelas cigarrinhas, quando os vetores foram expostos ao fitoplasma, e um efeito oposto para o caso do espiroplasma. Constataram também que a baixa taxa de transmissão, verificada em algumas espécies vetoras, esteve relacionada com a patogenicidade do fitoplasma ao inseto.

Quanto à eficácia da transmissão de fitoplasma por $D$. maidis, Leagrand \& Power (1994) verificaram que o periodo de aquisição acima de 2 horas e de inoculação superior a 30 minutos, respectivamente, exerce um efeito positivo na transmissão para o milho, obtendo-se o máximo de eficiência quando estes periodos são prolongados acima destes limites. Além disso, um aumento na taxa de transmissão do patógeno foi constatado quando a aquisição do fitoplasma ocorreu na fase de ninfa de $D$. maidis (Moya Raygoza \& Nault, 1998).

\subsection{Danos}

O complexo do enfezamento pode provocar reduções significativas na produção e na qualidade de grãos, principalmente nos 
plantios de safrinha, onde a incidência da doença tem atingido indices elevados (Massola Júnior et al., 1997; Oliveira et al., 1998).

Alguns relatos têm demonstrado as reduções nos componentes de produção em função da incidência do enfezamento vermelho/pálido. Massola Júnior et al. (1997), avaliando os danos provocados pelo complexo do enfezamento em ensaios de campo, verificaram reduçōes ao redor de 30\% da produção. Nos Estados Unidos, Scott et al. (1977) obtiveram reduções da ordem de $50 \%$ na produção de híbridos suscetiveis. Plantas adultas infectadas normalmente exibem acentuada redução da altura, proliferação de espigas pequenas, redução no número e no peso de sementes (Nault \& Bradfute, 1979; Scott et al., 1977). Sob condições de irrigação em lavouras brasileiras, foi observado até $100 \%$ de incidência de enfezamento resultando em perda quase total na produção do milho (Oliveira et al., 1998).

Scott et al. (1977), avaliando o efeito da época de aparecimento de sintoma sobre a produção, constataram um aumento da produção de grãos em função do atraso na expressão de sintomas. A produção foi nula sempre que o aparecimento de sintomas precedeu o $52^{\circ}$ dia, a contar da semeadura. Após o $52^{\circ}$ dia, para cada dia de atraso foi verificado um de ganho 1.82\% na produção e após 107 dias, a manifestação de sintomas mostrou não ter efeito na produção. Em estudos visando quantificar os danos decorrentes do enfezamento pálido e vermelho em condições de campo, Massola Júnior et al. (1999c) determinaram que a cada $1 \%$ de aumento na incidência, havia correspondência de $0.8 \%$ de perda na produção.

Plantas em diferentes estádios fenológicos respondem diferentemente à infecção pelo fitoplasma do enfezamento. Em plantas de milho expostas à infecção natural dos agentes dos enfezamentos nos intervalos de 0-10,10-20, 20-30 dias após a emergência, os danos na 
produção foram de 37, 21 e 28\%, respectivamente (Hruska \& Peralta, 1997). De maneira semelhante, Massola Júnior et al. (1999a) verificaram em plantas inoculadas com agente do enfezamento pálido uma redução de $64,49,53,26$ e $1 \%$ na produção e de $59,54,57,22$ e $0 \%$ no peso de 1000 grãos para parcelas inoculadas nos estádios I, II, III, V, VI respectivamente.

Considerando-se o complexo do enfezamento, o enfezamento vermelho tem se apresentado mais severo do que o enfezamento pâlido. Massola Júnior et al. (1998), avaliando o efeito da inoculação de espiroplasma e fitoplasma sobre o crescimento e produçāo de milho, constataram reduçōes de 69, 51 e $20 \%$ na produção de um híbrido suscetivel inoculado com fitoplasma, fitoplasma + espiroplasma e espiroplasma, respectivamente.

\subsection{Controle}

Segundo Oliveira et al. (1997), o escape de doenças transmitidas pela cigarrinha do milho pode ser obtido evitando-se os plantios tardios e consecutivos, que favorecem a sobrevivência do patógeno e do vetor.

A redução da dispersão da doença através de inseticidas foi relatada para poucos patossistemas, cujo patógeno associa-se persistentemente ao vetor. Bhirud \& Pitre (1972), testando vários inseticidas, verificaram que carbofuran e methomil aplicados no sulco foram efetivos no controle de $D$. maidis na ordem de 65 e 53\%, respectivamente. Waquil \& Viana (1996), avaliando a eficácia de inseticidas para controle de $D$. maidis, observaram que aldicab aplicado no tratamento de solo e imidacloprid aplicado na semente foram os 
melhores tratamentos, apresentando um efeito residual de 59 e 32 dias, respectivamente. Entretanto, o controle do enfezamento por meio do manejo do vetor é difícil devido a grande mobilidade de $D$. maidis nos campos e à eficiência na transmissão de patógenos (Hruska \& Peralta, 1997). Ainda que inseticidas possam reduzir a incidência da doença transmitida por insetos, a aplicação de agrotóxicos não garante a prevenção da dispersão da doença, pois a eficácia dos inseticidas não é instantânea e assim, na maioria das vezes, a dispersão da doença é inevitável (Bhirud \& Pitre, 1972). Além disso, embora o controle químico seja possivel, particularmente em campos de produção semente, atualmente não há no MAARA inseticidas registrados para controle de D. maidis na cultura do milho (Oliveira et al., 1997).

A medida de controle mais promissora é o uso de variedades resistentes e tolerantes (Tsai \& Falk, 1988). Apesar de haver muitos hibridos comerciais suscetiveis, materiais altamente resistentes têm sido encontrados em avaliações de incidência do enfezamento (Oliveira et al., 1997). Entre os hibridos de milho testados, G-85, Agromen 2003 e 2007 apresentaram as menores incidências de adultos da cigarrinha vetora (Waquil et al., 1996). Folegatti et al. (1997a) constataram em hibridos resistentes que a incidência do enfezamento sempre foi baixa (10\%) e de progresso lento. No entanto, pouco se conhece sobre a resistência genética do milho ao enfezamento e sobre os hibridos comerciais disponiveis, que apresentem resistência aliada a alta produtividade. 


\section{EFEITO DA POPULAÇĀO INFECTIVA DE Dalbulus maidis SOBRE A PRODUÇÃO DE GRÃOS E O DESENVOLVIMENTO DE SINTOMAS ASSOCIADOS AO FITOPLASMA DO ENFEZAMENTO VERMELHO DO MILHO}

\section{RESUMO}

O enfezamento vermelho, causado por fitoplasma, é uma doença que vem aumentando significativamente de importância, principalmente em função dos plantios sucessivos de milho. A transmissão ocorre por meio de cigarrinhas, destacando-se a espécie Dalbulus maidis. Visando-se determinar o efeito da populaçāo infectiva de $D$. maidis sobre a produção e o desenvolvimento de sintomas, plantas do hibrido suscetivel XLX 520, com 10 dias de idade, foram experimentalmente inoculadas com fitoplasma, em condiçōes de telado, por meio de 1, 3, 6 e 9 insetos infectivos por planta, confinados por 4 dias. Como testemunhas, foram usadas plantas infestadas com 1, 3, $6 \mathrm{e}$ 9 insetos sadios e plantas não infestadas por cigarrinhas. $O$ delineamento experimental foi inteiramente casualizado, com 6 repetiçōes. Os sintomas mais evidentes foram avermelhamento foliar, enfezamento generalizado e proliferação de espigas improdutivas. $O$ rendimento e a qualidade de grãos bem como a altura de plantas foram reduzidos à medida em que se aumentou a populaçāo de insetos 
infectivos. A incidência da doença e a severidade de sintomas foram maiores nas plantas inoculadas com as maiores densidades de insetos. Assim, reduções médias de 35.0, 53.7, 65.7 e 91.3\% foram constatadas quando se avaliou a produção de plantas inoculadas com 1, 3, 6 e 9 insetos infectivos por planta, respectivamente.

Palavras-chave: Zea mays, molicutes, cigarrinha do milho

\section{EFFECT OF THE INFECTIVE POPULATION OF Dalbulus maidis ON THE KERNEL YIELD AND SYMPTOM DEVELOPMENT ASSOCIATED WITH THE MAIZE BUSHY STUNT PHYTOPLASMA.}

\section{SUMMARY}

Maize bushy stunt is caused by a phytoplasma and its importance is increasing due successive corn cultivation. The pathogen is transmitted mainly by the leafhopper Dalbulus maidis. In order to evaluate the effect of the infective population of the vector on the grain yield and severity of symptoms, 10 days old plants belonging to the susceptible hybrid XLX 520 were inoculated with 1, 3, 6 and 9 insects, during 4 days. Controls were plants infested with healthy insects and plants not submitted to insect feeding. The most commom symptoms observed were red leaves, stunt and ear proliferation. Grain yield, kernel quality and height of plants were reduced as the infective population increased. On the other hand, incidence and severity of symptoms were higher as this population increased. Yield reductions of 35.0, 53.7, 65.7, $91.3 \%$ were obtained when plants were inoculated with $1,3,6$ e 9 infective insects, respectively. 


\subsection{INTRODUÇĀO}

O enfezamento vermelho do milho é uma doença causada por fitoplasma, um procarioto sem parede celular, limitado ao floema e transmitido, de maneira persistente e propagativa, por meio de insetos vetores do tipo cigarrinhas, destacando-se, nas nossas condições, a espécie Dalbulus maidis (DeLong \& Wolcott) (Madden \& Nault, 1983; Nault, 1980; Nault \& Bradfute, 1979). Relatado no Brasil na década de 70, o enfezamento foi considerado, na época, uma doença de importância secundária devido à baixa incidência (Costa et al., 1971). Contudo, a expansão dos plantios denominados "safrinha" e a adoção de irrigação proporcionaram, em alguns locais, a presença de milho no campo durante $o$ ano inteiro. Isso acarretou mudanças no comportamento de alguns patossistemas, principalmente naqueles envolvendo insetos vetores (Oliveira et al., 1997). Em particular ao enfezamento vermelho do milho, a doença vem aumentando significativamente de importância, sendo os prejuizos variáveis em função de plantios tardios e da suscetibilidade dos híbridos (Silva et al., 1991).

Com relação ao vetor, a cigarrinha $D$. maidis tem assumido papel relevante nos últimos anos, principalmente nas regiões Sudeste e Centro-Oeste do Brasil (Waquil et al., 1999). Segundo Waquil \& Fernandes (1992), os picos populacionais de $D$. maidis têm sido registrados nos meses de março e abril, aumentando a possibilidade da ocorrência do enfezamento no milho safrinha. De fato, as maiores incidências da doença estiveram correlacionadas com o aumento da densidade populacional do inseto em lavouras localizadas no Brasil Central (Oliveira et al., 1998). De maneira semelhante, Massola Júnior et al. (1997) verificaram que as maiores incidências da doença estiveram 
correlacionadas com as maiores reduções na produção $(30 \%)$, quando os plantios foram realizados em março. Entretanto, existem relatos de que a incidência do enfezamento não esteve correlacionada com o aumento da população do inseto vetor (Folegatti et al., 1997b; Hruska et al., 1996; Massola Júnior et al., 1999c).

Assim, o objetivo desse trabalho foi investigar o efeito do número de insetos infectivos sobre o estabelecimento e desenvolvimento da doença em plantas de milho, bem como avaliar o seu efeito sobre a produção e qualidade de grāos.

\subsection{MATERIAL E MÉTODOS}

\subsubsection{Instalaçāo do ensaio}

O ensaio foi conduzido em condições de telado, na área experimental do Setor de Fitopatologia da ESALQ/USP, no periodo de setembro/ 1999 a março/2000.

Visando garantir a uniformidade do ensaio, sementes do hibrido suscetivel XLX 520 foram pré-germinadas sobre duas folhas de papel umedecidas, contidas em bandejas plásticas, as quais foram cobertas com filme plástico transparente e colocadas em germinador a $25^{\circ} \mathrm{C}$, por 4 dias. Após a germinação, foi feito o plantio das sementes em copos plásticos $(250 \mathrm{ml})$ contendo uma misturà esterilizada composta de solo, areia e matéria orgânica, mantendo-se 1 planta/copo.

No décimo dia após o plantio, as plantas foram experimentalmente inoculadas com fitoplasma, por meio de 1, 3, 6 e 9 insetos infectivos por planta. Como testemunhas foram usadas plantas infestadas com 1, 3, 6 e 9 insetos sadios por planta e plantas sem 
infestação por inseto. Na inoculação, foram utilizadas gaiolas, representadas por garrafas plásticas de refrigerante de $2 \mathrm{~L}$, as quais confinaram os insetos sobre as plantas, por um periodo de 4 dias. Após o periodo de inoculação, as gaiolas e os insetos foram retirados e os ovos foram eliminados pela pulverização do inseticida sistêmico imidacloprid. Aos vinte dias após a inoculação, as plantas foram transferidas para sacos plásticos $(5 \mathrm{~L})$ contendo como substrato a mesma mistura anteriormente referida, porém suplementada com $12 \mathrm{~g}$ de sulfato de amônio acrescido da fórmula 4-14-8 (1:2), a cada 21 dias. $O$ delineamento experimental adotado foi inteiramente casualizado com 6 repetições, sendo cada parcela constituida por uma planta.

A colônia de insetos sadios foi obtida a partir de plantas de milho contendo posturas de adultos sadios de $D$. maidis, sendo os ovos depositados ao longo da nervura central das folhas. As plantas foram mantidas em gaiolas e com a eclosão das ninfas, iniciou-se a criação massal do inseto.

A obtenção de insetos infectivos foi feita de acordo com a metodologia descrita por Nault (1980). Ninfas de $2^{\circ}$ e $3^{\circ}$ instares, criadas em plantas sadias, foram transferidas para planta fonte infectada com fitoplasma. Os insetos foram confinados no cartucho da planta fonte, o hibrido XL 333, com 80 dias de idade, por meio de um saco de tecido (voil) preso ao ápice da planta. O período de aquísição foi de 4 dias, sendo as ninfas transferidas para plantas sadias, mantidas em gaiolas teladas, nas quais permaneceram por 21 dias, correspondendo ao periodo de latência.

As plantas contendo o inóculo e as posturas do inseto foram gentilmente fornecidas pelo Laboratório de Insetos Vetores do Setor de Entomologia da ESALQ/USP. A determinação da presença de fitoplasma 
e ausência de espiroplasma na planta fonte foi feita através das técnicas de PCR e de ELISA, respectivamente.

\subsubsection{Avaliação do ensaio}

\subsubsection{Sintomatologia e produção de grãos}

O ensaio foi avaliado semanalmente, a partir da inoculação, através da observação visual dos sintomas típicos da doença como clorose e avermelhamento foliar, redução no comprimento de entrenós, enfezamento da planta e proliferação de espigas. No estádio de grão pastoso (estádio 7, de acordo com Fancelli \& Lima, 1992), foram avaliados a altura de plantas, o número de espigas/planta e a incidência da doença, baseada na presença de um ou mais tipos de sintomas descritos anteriormente. Após a colheita das espigas maduras, foram determinados os parâmetros de produção através da determinação do peso de grãos, peso de mil grãos, número de grãos, comprimento de espigas e número de fileiras de grãos nas espigas. Os grãos foram secos a $105 \pm 2^{\circ} \mathrm{C}$ por $24 \mathrm{~h}$ e os valores das pesagens foram corrigidos para $12 \%$ de umidade.

\subsubsection{Teste de retenção de grãos em peneiras}

O comprometimento da qualidade dos grãos, provocado pela doença, foi avaliado com base no tamanho dos grãos, pelo teste de retenção em peneiras. O procedimento utilizado foi separar os grãos num conjunto de 8 peneiras de malhas circulares, de diferentes 
diâmetros decrescentes, variando de 9.52 a $7.14 \mathrm{~mm}$. Foi determinado o peso de grãos retidos em cada peneira e aqueles que passaram pela peneira $7.14 \mathrm{~mm}$. A porcentagem de retenção de grãos foi calculada para cada tratamento.

\subsubsection{Teste de germinação de sementes}

A germinação das sementes foi determinada pelo teste padrão de germinação, de acordo com as Regras para Análise de Sementes (Brasil, 1992). Foram tomadas, ao acaso, 50 sementes de cada tratamento e distribuidas, de maneira uniforme, sobre duas folhas de papel de germinação umedecidas. As sementes foram cobertas por uma terceira folha, sendo o conjunto enrolado. Em seguida, os rolos, devidamente identificados, foram colocados verticalmente numa cesta de arame e incubados em germinador, a $25^{\circ} \mathrm{C}$. As avaliações foram realizadas aos 4 e 7 dias de incubação, através da contagem de plântulas normais, sendo determinada a porcentagem de germinação. $O$ delineamento experimental foi inteiramente casualizado, com 4 repetições.

\subsubsection{Testes de PCR e ELISA}

Os testes de PCR e de ELISA foram realizados visando monitorar a presença de fitoplasma associado às plantas sintomáticas e, ao mesmo tempo, demonstrar a ausência de espiroplasma nestas plantas. As amostragens foram feitas dentro de plantas experimentalmente inoculadas. Partes de folhas foram coletadas no 
estádio de grão pastoso, e a partir delas foi feita a extração de DNA para uso no PCR. Este foi conduzido segundo a metodologia descrita por Lee et al. (1993). O controle positivo foi representado pelo DNA extraído de amostras foliares da planta fonte e como controles negativos foram usados água e DNA proveniente de plantas sadias de milho. Os produtos de PCR foram analisados por eletroforese em gel de agarose 1\%. Após a coloração com brometo de etídio, bandas de DNA foram visualizadas num transluminador de luz ultravioleta. O padrão de peso molecular utilizado no gel de agarose foi de 1,2 kb DNA lader.

Amostras foliares de plantas inoculadas foram coletadas $\mathrm{e}$ submetidas ao teste de PTA-ELISA com antissoros policlonal para Spiroplasma kunkelii, utilizando fosfatase alcalina e o fosfato de nitrofenil como enzima e substrato, respectivamente. Amostras de plantas sadias e de planta fonte foram utilizadas como controle negativo; como controle positivo foram empregadas amostras de plantas exibindo sintomas típicos de infecção por espiroplasma, coletadas no campo. Foram consideradas positivas as amostras que apresentaram valores de absorbância no minimo duas vezes maior que o apresentado pelo controle sadio.

\subsubsection{Análise estatística}

A análise dos dados foi realizada por meio do programa SAS for Windows (SAS Institute, Cary, NC). Os dados originais foram utilizados para os parâmetros altura de plantas, comprimento de espigas, produção de grãos e peso de mil grãos, sendo os dados transformados em $\sqrt{ } x+1$ para o número de espigas, número de fileiras por espigas e 
número de grāos. As análises foram realizadas através do teste Tukey ao nivel de $5 \%$ de probabilidade.

\subsection{RESULTADOS}

\subsubsection{Desenvolvimento de sintomas}

Os primeiros sintomas se tornaram evidentes a partir dos 30 dias após a inoculação das plantas, sendo observado, inicialmente, o desenvolvimento de estrias cloróticas nos bordos e ápice das folhas, seguido por um avermelhamento destas áreas. Com o progresso da doença, foi constatada variação tanto nos graus de clorose como de avermelhamento, sendo estes sintomas mais acentuados nas folhas mais velhas. Além de clorose e avermelhamento, outros tipos de sintomas foram observados em plantas inoculadas, tais como folhas retorcidas, perfilhos laterais, brotaçōes axilares nas folhas, entrenós e pendões curtos, colmos afilados, enfezamento de plantas, proliferação de espigas anormais e alta ocorrência de grãos mal formados (Figura 1).

Os sintomas foram, proporcionalmente, mais severos, à medida em que se aumentou progressivamente o número de insetos infectivos confinados às plantas. Plantas infestadas por insetos sadios e plantas não submetidas à infestação de cigarrinhas não mostraram qualquer tipo de sintoma relacionado à doença. 


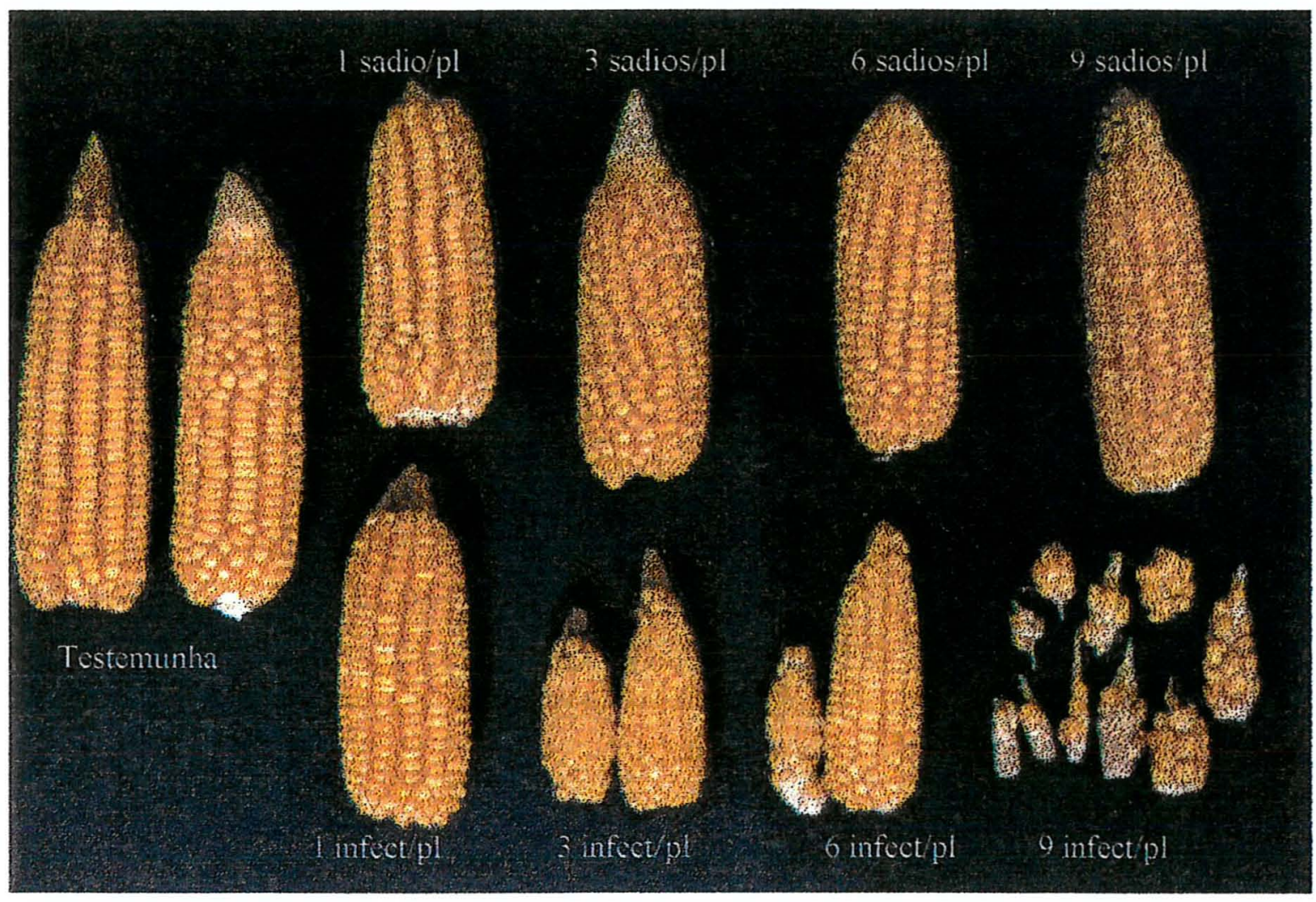

Figura 1. Efeito da população infectiva de $D$. maidis sobre as espigas de plantas de milho, híbrido XLX 520, inoculadas com fitoplasma do enfezamento. 


\subsubsection{Incidência da doença}

Niveis crescentes de incidência foram proporcionais ao número de insetos infectivos utilizados nas inoculações (Tabela 1). Assim, no tratamento em que as plantas foram inoculadas com 1 inseto, somente 1 das seis plantas manifestou os sintomas. Quando 3 insetos foram utilizados, apareceram sintomas em 2 das seis plantas inoculadas. No entanto, quando as plantas foram inoculadas com 6 insetos, os sintomas da doença foram observados em 5 das seis plantas. Finalmente, todas as plantas inoculadas com 9 cigarrinhas infectivas desenvolveram sintomas tipicos da doença. Plantas testemunhas, ou seja, aquelas livres de insetos e plantas submetidas a insetos sadios não exibiram sintomas de enfezamento.

\subsubsection{Altura de plantas e produção de grãos}

Os dados, apresentados na Tabela 1, mostram que a altura de plantas e a produção de grãos foram significativamente reduzidos em alguns tratamentos, em função do nưmero de insetos infectivos utilizados na inoculação. Por outro lado, em plantas testemunhas mantidas livres de insetos e naquelas submetidas a insetos sadios não foi constatada redução significativa tanto na altura como na produção de grãos.

Quanto à altura de plantas, podem ser caracterizados dois grupos distintos. Num primeiro grupo, as plantas inoculadas com 1 e 3 insetos, nas quais não houve redução em relação às testemunhas e no outro grupo, plantas inoculadas com 6 e 9 insetos, nas quais ocorreu redução significativa na altura em relação às testemunhas. No entanto, 
apesar das plantas inoculadas com 9 insetos terem apresentado a média mais baixa de altura, estas não diferiram estatisticamente das plantas inoculadas com 6 insetos infectivos. Para o tratamento com 6 insetos, os valores médios de redução da altura ficaram em torno de $36 \%$, enquanto com 9 insetos, a altura das plantas foi reduzida em 44\%, aproximadamente.

Tabela 1. Incidência do enfezamento vermelho, altura de plantas e produção de grãos por plantas do híbrido XLX 520, não submetidas à alimentação de insetos (testemunha), submetidas a insetos sadios $\mathrm{e}$ inoculadas com insetos infectivos.

\begin{tabular}{|c|c|c|c|}
\hline Tratamento & Incidência & $\begin{array}{l}\text { Altura } \\
(\mathrm{m})^{*}\end{array}$ & $\begin{array}{l}\text { Produção de grãos } \\
\qquad(\mathrm{g} / \mathrm{p} 1)^{*}\end{array}$ \\
\hline Testemunha & $0 / 0$ & $2.33 \mathrm{a}$ & $109.03 \mathrm{a}$ \\
\hline Um inseto sadio & $0 / 0$ & $2.33 \mathrm{a}$ & $92.19 \mathrm{ab}$ \\
\hline Três insetos sadios & $0 / 0$ & $2.25 \mathrm{a}$ & $99.44 \mathrm{ab}$ \\
\hline Seis insetos sadios & $0 / 0$ & $2.45 \mathrm{a}$ & $80.70 \mathrm{abc}$ \\
\hline Nove insetos sadios & $0 / 0$ & $2.15 \mathrm{a}$ & $92.52 a b$ \\
\hline Um inseto infectivo & $1 / 6$ & $2.03 \mathrm{a}$ & $70.92 \mathrm{bc}$ \\
\hline Três insetos infectivos & $2 / 6$ & $2.14 \mathrm{a}$ & 50.51 \\
\hline Seis insetos infectivos & $5 / 6$ & $1.48 \mathrm{~b}$ & 37.42 \\
\hline Nove insetos infectivos & $6 / 6$ & $1.30 \mathrm{~b}$ & 9.47 \\
\hline CV \% & & 12.57 & 23.84 \\
\hline
\end{tabular}

*valores médios de 6 plantas, por tratamento

Médias seguidas pelas mesmas letras na coluna não diferem entre si pelo teste de Tukey, ao nivel de $5 \%$ de probabilidade. 
A produção de grãos pelas plantas inoculadas, independentemente do número de insetos utilizados, foi significativamente menor do que pelas plantas testemunhas, mantidas livres de insetos (Tabela 1). Plantas testemunhas produziram, em média, $109,03 \mathrm{~g} /$ planta, enquanto as plantas inoculadas apresentaram uma produção média de $42,08 \mathrm{~g}$ /planta. Quando 1, 3, 6 e 9 insetos foram empregados na inoculação, foram constatadas reduções na produção da ordem de $35.0 \%, 53.6 \%, 65.6 \%$ e $91.3 \%$, respectivamente. Os dados revelaram também que a presença de insetos sadios não interferiu de modo significativo na produção de plantas, quando comparadas com plantas testemunhas (Tabela 1). No entanto, em termos médios, houve uma tendência de redução na produção de grãos, pois plantas submetidas aos insetos sadios tiveram sua produção reduzida em média de $16.3 \%$.

\subsubsection{Componentes de produçāo}

Dentro deste item foram avaliados o número de espigas por planta, comprimento de espigas, número de fileiras de grãos, número de grãos por planta e peso de mil grãos (Tabela 2).

A produção de espigas anormais extranumerárias, caracterizadas por serem de tamanho reduzido, mal formadas e com granação irregular se constitui num dos sintomas indicativos da presença de fitoplasma em plantas de milho. As plantas inoculadas apresentaram, na sua maioria, um número de espigas significativamente maior que aquelas não inoculadas. No tratamento em que as plantas foram inoculadas com 9 insetos/planta, estas plantas chegaram a produzir uma média de até 3.8 espigas anormais/planta. No 
entanto, plantas testemunhas mantidas livres de insetos e aquelas submetidas à infestação por insetos sadios apresentaram somente uma espiga normal/planta.

Tabela 2. Efeito da população infectiva de $D$. maidis sobre os componentes de produção de plantas do híbrido XLX 520, inoculadas com fitoplasma do enfezamento vermelho.

\begin{tabular}{|c|c|c|c|c|c|}
\hline \multirow[t]{2}{*}{ Tratamento } & \multicolumn{5}{|c|}{ Componentes de produção } \\
\hline & $\mathrm{NE}$ & $\mathrm{CE}$ & $\mathrm{NF}$ & NG & PMG \\
\hline Testemunha & $1.0 \mathrm{~b}$ & $14.5 \mathrm{a}$ & $12.6 \mathrm{a}$ & $381.3 \mathrm{a}$ & $288.1 \mathrm{a}$ \\
\hline 1 inseto sadio & $1.0 \mathrm{~b}$ & $13.9 \mathrm{a}$ & $12.9 \mathrm{a}$ & $325.0 \mathrm{ab}$ & $287.0 \mathrm{a}$ \\
\hline 3 insetos sadios & $1.0 \mathrm{~b}$ & $13.3 \mathrm{a}$ & $14.6 \mathrm{a}$ & $368.6 \mathrm{a}$ & $273.4 \mathrm{ab}$ \\
\hline 6 insetos sadios & $1.0 \mathrm{~b}$ & $12.8 \mathrm{a}$ & $13.3 \mathrm{a}$ & $307.3 \mathrm{ab}$ & $265.1 \mathrm{ab}$ \\
\hline 9 insetos sadios & $1.0 \mathrm{~b}$ & $13.2 \mathrm{a}$ & $12.3 \mathrm{a}$ & $328.6 \mathrm{ab}$ & $282.7 \mathrm{a}$ \\
\hline 1 inseto infectivo & $1.6 \mathrm{ab}^{*}$ & $11.1 \mathrm{ab}$ & $13.2 \mathrm{a}$ & $254.6 \mathrm{ab}$ & $281.4 \mathrm{a}$ \\
\hline 3 insetos infectivos & $1.3 \mathrm{~b}^{*}$ & $11.0 \mathrm{ab}$ & $12.9 \mathrm{a}$ & $248.1 \mathrm{ab}$ & $230.5 \mathrm{abc}$ \\
\hline 6 insetos infectivos & $1.9 \mathrm{ab}^{*}$ & 7.5 & $10.2 \mathrm{ab}$ & $200.6 \mathrm{bc}$ & 184.4 bc \\
\hline 9 insetos infectivos & $3.8 \mathrm{a}^{*}$ & 4.3 & $5.9 \quad \mathrm{~b}$ & $63.16 \mathrm{c}$ & 160.1 \\
\hline CV \% & 21.31 & 18.55 & 11.22 & 18.36 & 20.45 \\
\hline
\end{tabular}

Componentes de produção: valores médios de 6 plantas por tratamento $\mathrm{NE}$ número de espigas por planta (* espigas improdutivas)

$\mathrm{CE}$ comprimento de espiga, $\mathrm{cm}$ NF número de fileiras por espiga NG número de grãos por planta PMG peso de mil grãos, em gramas Médias seguidas pelas mesmas letras na coluna não diferem entre si pelo teste de Tukey, ao nivel de $5 \%$ de probabilidade. 
Quanto ao tamanho de espigas, os resultados mostraram que houve uma redução significativa no comprimento de espigas produzidas pelas plantas inoculadas com 6 e 9 insetos/planta, quando comparadas com as plantas pertencentes aos demais tratamentos. Nestes casos, reduçōes da ordem de $48.3 \%$ e $70.3 \%$ foram constatadas para plantas submetidas a 6 e 9 insetos infectivos, respectivamente, em relação às testemunhas mantidas livres de insetos.

O número de fileiras por espiga foi drasticamente reduzido em espigas produzidas por plantas inoculadas com 9 insetos/planta. Plantas sadias apresentaram espigas com número médio em torno de 12-13 fileiras, enquanto espigas originárias de plantas inoculadas com 9 insetos apresentaram a metade deste número. Para os demais tratamentos com insetos infectivos, a redução no número de fileiras por espiga não foi significativa.

Os resultados obtidos para o parâmetro número de grãos por planta foram semelhantes àqueles registrados para fileiras por espiga. Assim, o mais elevado valor de redução foi constatado em espigas produzidas por plantas inoculadas com 9 insetos/planta. O número mèdio de grãos/planta contado neste tratamento foi de 63.16 enquanto a média para plantas testemunhas foi de 381.3, correspondendo a uma redução de $83.4 \%$.

O peso de mil grãos seguiu a mesma tendência dos resultados obtidos para número de fileiras e de grãos. Em plantas inoculadas com nove insetos ocorreu uma redução significativa no peso, em comparação com as plantas pertencentes aos demais tratamentos. Em plantas testemunhas o peso médio de mil grãos atingiu $288.1 \mathrm{~g}$, enquanto em plantas inoculadas com 9 insetos este valor caiu para 160.1g. Em termos percentuais houve uma redução drástica da ordem de $44.4 \%$. 
Os resultados, apresentados na Figura 2, demonstram claramente que os danos causados pelo enfezamento vermelho na altura de plantas e nos componentes de produção foram proporcionalmente maiores à medida em que se aumentou o número de insetos infectivos por planta. Um efeito negativo sobre os componentes de produção foi constatado quando plantas de milho foram submetidas às populações sadias de $D$. maidis, porém este efeito não foi estatisticamente significativo. 
Altura de plantas

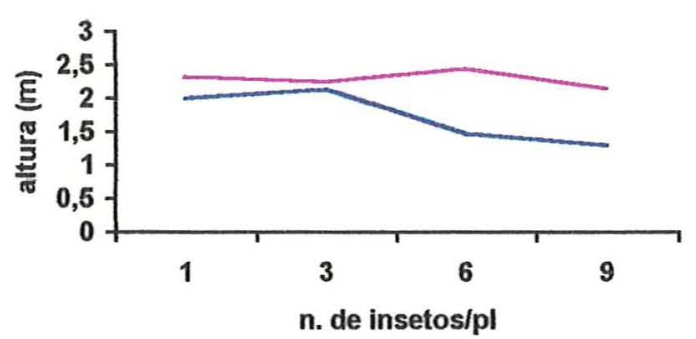

tamanho das espigas

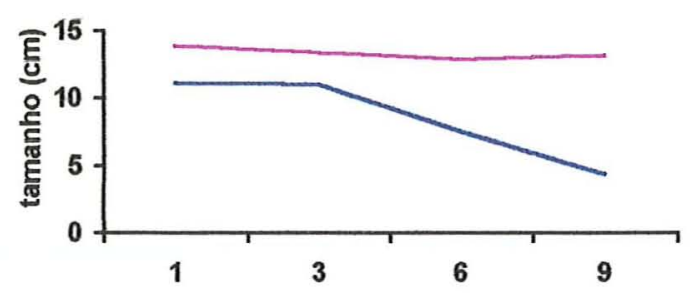

n. de insetos/pl

número de grãos/planta

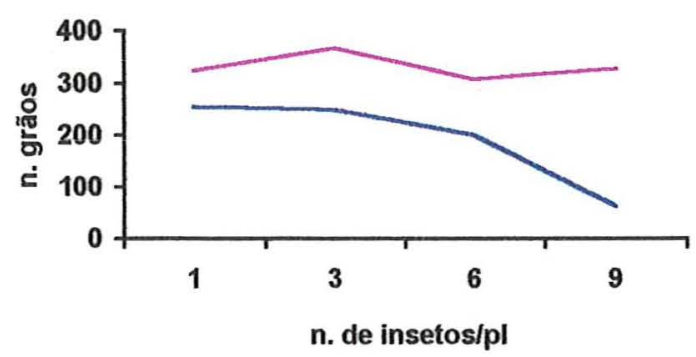

Produção de grãos

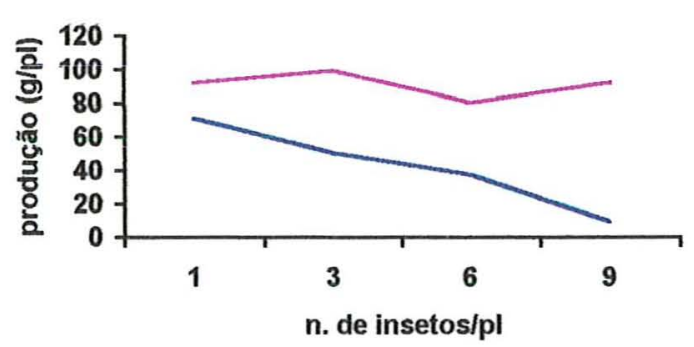

número de espigas/planta

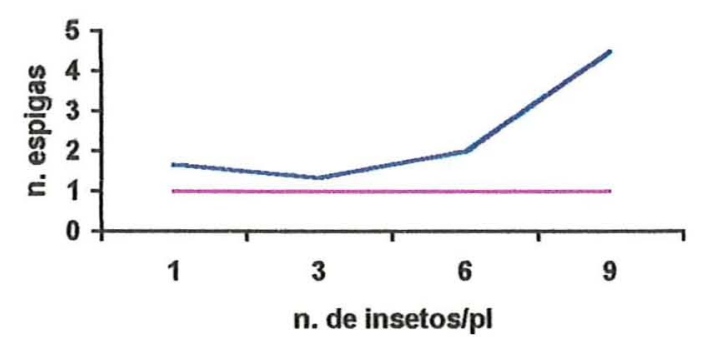

número de fileiras/espiga

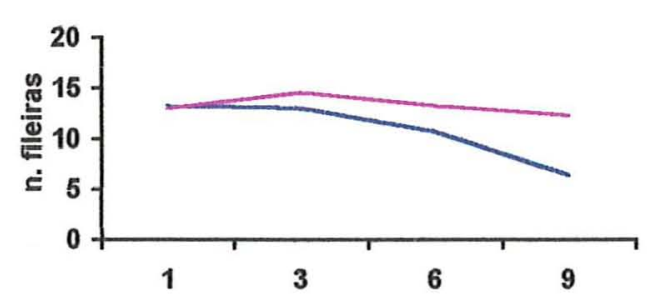

n. de insetos/pl

Peso de mil grãos

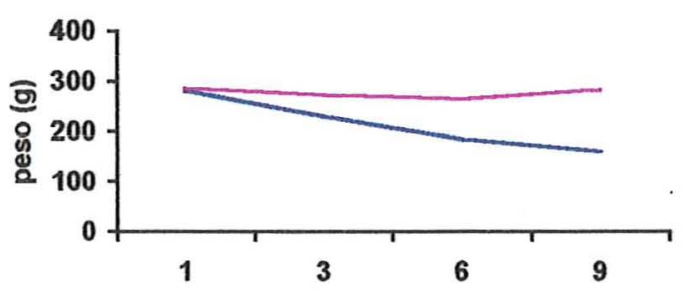

n. de insetos/pl

Figura 2. Efeito da população infectiva de D. maidis sobre a altura e os componentes de produção de plantas de milho inoculadas com o fitoplasma do enfezamento.

População infectiva

População sadia o fitoplasma do enfezamento. 


\subsubsection{Teste de retenção de grãos em peneiras}

Quanto ao tamanho dos grãos, os resultados obtidos pelo teste de retenção dos grãos em peneiras revelaram que em plantas testemunhas não submetidas ao vetor, somente $8.6 \%$ dos grãos ficaram retidos ou passaram pela peneira de malha de menor diâmetro $(7.14 \mathrm{~mm})$. No entanto, para plantas inoculadas com 1, 3, 6 e 9 insetos, respectivamente, 24.9, 40.6, 70.0 e $83.2 \%$ dos grãos produzidos foram retidos ou passaram por esta mesma peneira (Figura 3). Esses dados demonstraram que a quantidade de grãos miúdos produzidos pela plantas inoculadas foi diretamente proporcional ao número de insetos infectivos.



Figura 3. Efeito da população infectiva de $D$. maidis sobre o tamanho de grãos, avaliado através de um conjunto de peneiras de malhas circulares, produzidos por plantas de milho inoculadas com o fitoplasma do enfezamento. 
O tamanho dos grãos produzidos em plantas submetidas à infestação de insetos sadios foi semelhante aquele constatado para as plantas testemunhas, livres de insetos.

\subsubsection{Teste de germinação de sementes}

Os resultados obtidos no teste de germinação mostraram que as menores porcentagens de germinação ocorreram nos lotes de sementes originários de plantas inoculadas. À medida em que o número de insetos infectivos aumentou, houve, proporcionalmente, redução nas porcentagens de germinação de sementes. Assim, porcentagens da ordem de 98.5, 95, 93 e 83.5 foram obtidas para as sementes produzidas pelas plantas inoculadas com 1, 3, 6 e 9 insetos infectivos, respectivamente. Em contraste, as sementes originárias de plantas testemunhas apresentaram $100 \%$ de germinação, enquanto porcentagens de $99.5,99,99.5$ e 99.5 foram registradas para sementes produzidas pelas plantas submetidas a $1,3,6$ e 9 insetos sadios, respectivamente.

\subsubsection{Testes de PCR e ELISA}

$O$ teste de PCR confirmou a presença de fitoplasma na amostragem feita a partir de plantas inoculadas que exibiam sintomas caracteristicos de enfezamento vermelho. Plantas assintomâticas sadias e testemunhas não revelaram a presença de fitoplasma em seus tecidos. A análise dos produtos de PCR utilizando iniciadores universais evidenciou a ocorrência de bandas de $1,2 \mathrm{~kb}$ no gel de agarose, bandas estas tipicamente produzidas por fitoplasmas. 
O teste ELISA confirmou a ausência de espiroplasma nas plantas amostradas que apresentavam sintomas de enfezamento vermelho, demonstrando que as mesmas não apresentavam infecções mistas. A ausência de espiroplasmas também foi constatada para a planta que serviu de fonte de inóculo para as plantas experimentalmente inoculadas através de insetos.

\subsection{DISCUSSÃO}

Os sintomas observados nas plantas inoculadas foram tipicamente aqueles relatados para plantas infectadas com o fitoplasma do enfezamento (Bedendo, 1999; Nault, 1980; Oliveira et al., 1997). Os sintomas mais evidentes foram o avermelhamento foliar, a proliferação de espigas anormais e o enfezamento da planta. Estes sintomas, têm sido os mais utilizados para fins de diagnose do enfezamento vermelho do milho, embora os mesmos também possam estar associados à infecção causada por espiroplasmas (Bedendo, 1997; Massola Júnior et al., 1999c). No presente trabalho, os testes de PCR e de ELISA demonstraram que estes sintomas estavam associados à presença de fitoplasma, pois este patógeno foi detectado nas plantas amostradas, as quais se mostraram livres de espiroplasmas. $O$ fato dos sintomas terem sido mais drásticos em plantas inoculadas com maior número de insetos evidenciou que a quantidade de inôculo inicial transmitido às plantas pode ter influenciado o desenvolvimento da doença, tornando-a mais severa nas plantas que receberam maior carga de inóculo, decorrente da presença de um maior número de insetos infectivos confinados sobre as mesmas. 
A incidência de ambas as formas de enfezamento tem sido registrada em condições de campo, em regiōes produtoras de milho. Avaliações realizadas, em condições brasileiras, têm demonstrado que os enfezamentos têm ocorrido com alta incidência atingindo valores variáveis de $65.3 \%$ a $100 \%$, na região do Brasil Central (Oliveira et al., 1998). Em levantamentos realizados no Estado de São Paulo foram constatadas para híbridos mais suscetiveis porcentagens de incidência da ordem de até $47 \%$ (Dudienas et al., 1997).

Embora uma alta incidência da doença no campo tenha sido atribuída à presença de uma alta população de $D$. maidis (Oliveira et al., 1998), em outros trabalhos conduzidos tanto no Brasil como no exterior, têm sido demonstrado uma ausência de correlação positiva entre incidência de enfezamentos e densidade populacional do inseto vetor (Folegatti et al., 1997b; Hruska \& Peralta, 1997; Massola Júnior et al., 1999c). Nestes casos, tem sido relatado que o aumento da incidência estaria relacionado não com o aumento do número de insetos, mas sim com o aumento da porcentagem de insetos infectivos dentro da população do vetor. No entanto, estas observações foram feitas sem que se conhecesse a porcentagem de insetos infectivos presentes na população do campo. Contudo, os resultados obtidos no presente trabalho, conduzido sob condições controladas, vêm de encontro a estas observaçōes, pois demonstraram uma correspondência direta entre aumento de incidência e aumento de insetos infectivos. A mesma consideração é válida também para os sintomas, pois o aumento na severidade dos sintomas foi proporcional ao aumento do número de insetos infectivos utilizados na inoculação da plantas.

A altura das plantas inoculadas com 6 e 9 insetos foi significativamente menor em relação às plantas inoculadas com 1 e 3 insetos. Estes resultados seguiram as mesmas tendências verificadas 
para sintomas e incidência. Como os sintomas foram mais severos em plantas inoculadas com os maiores números de insetos e como o encurtamento de entrenós é um dos sintomas provocados pela doença, é perfeitamente justificável a ocorrência de maior redução na altura das plantas mais severamente afetadas pela doença. Os resultados obtidos para este parâmetro eram previsíveis, pois a diminuição na altura de plantas é um sintoma comumente observado, estando relacionado tanto com a ocorrência de fitoplasma como de espiroplasma (Bedendo, 1999; Nault, 1980; Shurtleff, 1986).

A redução na produção de grãos, constatada em plantas inoculadas, foi significativa, quando comparada com as plantas testemunhas. Dentre as plantas inoculadas, as maiores reduções, bem como os maiores niveis de incidência, foram proporcionais à maior população de insetos infectivos. Redução de até $91.3 \%$ foram registradas para plantas inoculadas com 9 insetos. Resultados semelhantes foram obtidos por Massola Júnior e colaboradores (1999c), os quais demonstraram, em condições de campo, que para cada $1 \%$ de aumento na incidência de enfezamentos, houve $0.8 \%$ de redução na prođução de grãos. Em plantios comerciais, instalados no Brasil Central, altos niveis de incidência de enfezamentos foram relacionados com alta redução na produção de grãos, havendo áreas onde a produção foi nula (Oliveira et al., 1998). Trabalhos de campo, conduzidos por Scott et al. (1977) nos Estados Unidos, também revelaram que a produção foi reduzida, em até $50 \%$, devido à alta freqüência de ocorrência de enfezamentos, porêm chegou a ser nula quando as plantas foram infectadas nos primeiros estádios de desenvolvimento. Em ensaios realizados com a inoculação de espiroplasma em plantas de milho mantidas em telado, Massola Jûnior et al. (1999a) verificaram que plantas inoculadas com 5 insetos infectivos, aos dez dias após a emergência, tiveram sua produção 
reduzida em 64\%. Estes relatos, dão suporte aos resultados obtidos neste trabalho, confirmando que a alta incidência de enfezamentos está diretamente relacionada com alta perda de produção. Isto demonstra, mais uma vez, que ambas as formas de enfezamento são altamente destrutivas e mesmo limitantes para a cultura do milho, principalmente quando são utilizados híbridos suscetiveis, na presença de alta população de insetos infectivos e em condições favoráveis ao desenvolvimento destas doenças.

A produção de espigas anormais foi constantemente observada em plantas inoculadas. Quando comparadas com plantas sadias, o número de espigas chegou a dobrar nas plantas submetidas a 6 insetos infectivos. No entanto, o número de espigas quadruplicou nas plantas inoculadas com 9 insetos infectivos. Como a severidade de sintomas foi proporcional ao maior número de insetos infectivos usados nas inoculações, a alta ocorrência de espigas anormais nas plantas inoculadas com altas populações de inseto está dentro dos resultados esperados. Apesar da proliferaçāo de espigas mal formadas se constituir num sintoma comumente exibido por plantas infectadas por fitoplasma (Bedendo, 1999; Massola Júnior et al., 1997; Nault, 1980; Oliveira, et al., 1998; Shurtleff, 1986), ficou evidente que o número de espigas produzidas foi relacionado com o número de insetos infectivos que se alimentaram nas plantas. Nestas espigas anormais foram observadas também a deformação das extremidades das brácteas, as quais passaram a desenvolver estruturas semelhantes às folhas, sintoma este conhecido por filodia. Embora o fenômeno de filodia seja, de modo geral, um sintoma típico provocado por fitoplasma, esta caracteristica pode estar associada também as causas genéticas.

As espigas anormais apresentaram tamanho reduzido em relação às espigas produzidas por plantas testemunhas. A redução 
chegou a $48.3 \%$ em plantas inoculadas com 6 insetos e a $70.3 \%$ quando 9 insetos foram utilizados nas inoculaçōes. O número de fileiras por espiga também foi uma das características alteradas pelo número de insetos infectivos, tendo sido reduzido, praticamente, à metade quando as plantas foram inoculadas com 9 insetos. O efeito da inoculação realizada com alta população de vetores também foi expressivo sobre o número de grãos presentes em espigas produzidas por plantas inoculadas. Neste caso, as plantas testemunhas produziram, em média, seis vezes mais grãos do que as plantas inoculadas com 9 insetos infectivos. De modo geral, a menor ou maior redução no tamanho das espigas, número de fileiras por espiga e número de grãos por planta deve estar relacionada com a menor ou maior suscetibilidade do híbrido. No entanto, ficou demonstrado que mesmo se utilizando um híbrido suscetivel, o número de insetos infectivos poderá determinar maior ou menor dano. Isto ficou evidente neste trabalho, pois somente em plantas inoculadas com alta população do inseto foram constatadas diferenças significativas para estes parâmetros, considerando-se plantas infectadas e não infectadas. A literatura registra a proliferação de espigas anormais em plantas infectadas tanto por fitoplasma como para espiroplasma (Bedendo, 1999; Massola Júnior et al., 1997; Nault, 1980; Oliveira, et al., 1998; Shurtleff, 1986), porém não faz referência ao tamanho apresentado por estas espigas, nem ao número de fileiras ou de grãos presentes na mesmas. Além disso, não se encontram relatos sobre avaliação destes parâmetros relacionando plantas infectadas e sadias, os quais demonstrem a influência da população de insetos sobre estes fatores de produção.

Em ensaios instalados no campo, sob condições naturais de infecção, ficou comprovado que o enfezamento causa redução significativa no rendimento e na qualidade de grãos, em função da mal 
formação de espigas, as quais produziram grãos de tamanho pequeno e com baixo peso específico (Massola Júnior et al., 1999a). Resultados semelhantes foram obtidos neste ensaio, no qual foi constatado que uma população elevada de insetos infectivos provoca maior proliferaçāo de espigas anormais, o que causou uma redução no rendimento das plantas inoculadas. 


\section{EFEITO DA INOCULAÇĀO DO FITOPLASMA DO ENFEZAMENTO SOBRE O DESENVOLVIMENTO E PRODUÇÃO DE HIBRIDOS DE MILHO}

\section{RESUMO}

O enfezamento vermelho do milho, associado a um fitoplasma, tem ocorrido com alta frequeência em razão da predominância de hibridos suscetiveis, plantios tardios e da alta população do vetor. Em condiçōes naturais, o fitoplasma ocorre formando um complexo com o espiroplasma, agente do enfezamento pálido, ambos transmitidos pela cigarrinha Dalbulus maidis (DeLong \& Wolcott). Visando estudar, em condições controladas, o efeito isolado do fitoplasma sobre o desenvolvimento e a produção de grãos, dez híbridos de milho, com graus variáveis de suscetibilidade, foram inoculados experimentalmente com fitoplasma por meio de 10 cigarrinhas infectivas por planta. Plantas infectadas foram comparadas com plantas sadias quanto à sintomatologia e à alteração de alguns fatores de produção. Em plantas inoculadas, foram observados sintomas tipicos de avermelhamento foliar, proliferação de espigas anormais, entrenós e pendão curtos, brotações axilares nas folhas e enfezamento em maior ou menor grau, em função de cada híbrido. Para os hibridos mais suscetiveis, além da grande proporção de grãos miúdos, foram constatadas reduções de até 
$35 \%$ na altura de plantas, $98 \%$ na produção de grãos, $89 \%$ no tamanho de espigas, $50 \%$ no número de fileiras/espiga, $98 \%$ no número de grãos/planta e $18 \%$ na germinação de sementes.

Palavras-chaves: molicutes, Zea mays, avermelhamento do milho

\section{EFFECT OF THE INOCULATION OF THE MAIZE BUSHY STUNT PHYTOPLASMA ON THE DEVELOPMENT AND KERNEL YIELD OF CORN HYBRIDS}

\section{SUMMARY}

Maize bushy stunt, caused by a phytoplasma, occurs with high frequency due to the prevalence of susceptible hybrids, late planting and high level of vector population. Usually, in the field conditions, the phytoplasma is associated with the corn stunt spiroplasma, constituting a complex. In this work, it was evaluated the single effect of the phytoplasma on the development and yield of ten corn hybrids. Ten days old plants, were experimentally inoculated using ten infective insects of Dalbulus maidis/plant. Infected and healthy plants were compared in relation to symptoms and yield components. Infected plants exhibited predominantly reddening of leaves, ear proliferation and stunting in different intensity. Hybrids showed variation in relation to reduction in height of plants and kernel yield. The most susceptible hybrids reached reductions as high as $35 \%$ in height of plants, $98 \%$ in kernel yield and number of grains/ear, $89 \%$ in ear size, $50 \%$ in number of lines/ear and $18 \%$ in seed germination. 


\subsection{INTRODUÇĀo}

O enfezamento vermelho do milho é uma doença importante, provocando redução no rendimento da cultura e na qualidade dos grãos (Hruska et al., 1996; Massola Júnior et al., 1997; Oliveira et al., 1998; Scott et al., 1977). Associada a um fitoplasma, organismo procarioto desprovido de parede celular e habitante de floema, a doença é disseminada por meio da cigarrinha do milho Dalbulus maidis (DeLong \& Wolcott) (Naut, 1980).

A incidência do enfezamento vermelho e o comprometimento da produção dependem, sobretudo, da suscetibilidade do híbrido, da população de vetores e do estádio de desenvolvimento das plantas na época de infecção (Bedendo, 1999; Hruska \& Peralta, 1997; Massola Júnior et al., 1999b; Oliveira et al., 1998; Scott et al., 1977). Altas incidências do enfezamento têm sido constatadas no campo em diferentes regiões brasileiras, principalmente naquelas em que se realiza plantios tardios e/ou consecutivos. Os plantios tardios, que constituem o chamado milho de safrinha, são geralmente os mais afetados pelo enfezamento em funçāo da ocorrência de altas populaçōes do vetor, verificadas durante os meses de março e abril (Waquil \& Fernandes, 1992). Avaliações sobre o comportamento de variedades e híbridos de milho têm revelado variaçōes enormes quanto ao grau de resistência dos materiais testados, havendo uma predominância de genótipos altamente suscetiveis (Borges, 1997; Dudienas et al., 1997; Oliveira et al., 1998). Em condiçōes de campo, muitos materiais de milho têm sido avaliados visualmente por meio de sintomas exibidos pela planta. No entanto, nestas condições podem ocorrer um complexo de doenças formado pelo enfezamento vermelho e pálido, este último causado por um espiroplasma. Assim sendo, torna-se dificil separar os efeitos individuais 
de cada componente do complexo, quanto à expressão de sintomas e danos causados à produção. Um dos raros trabalhos em que se estudou o efeito isolado destes patógenos foi conduzido por Massola Júnior et al. (1999a), os quais avaliaram o efeito da época de inoculação de espiroplasma sobre os diversos componentes de produção de dois hîbridos suscetiveis. No entanto, informações sobre o efeito isolado do fitoplasma do milho sobre desenvolvimento de sintomas e, principalmente, sobre os componentes de produção são bastante escassas.

O presente trabalho teve por objetivo avaliar o efeito do fitoplasma sobre a sintomatologia e os componentes de produção de diversos híbridos de milho.

\subsection{MATERIAL E MÉTODOS}

O ensaio foi conduzido em condiçōes de telado anti afídeo, da área experimental do setor de Fitopatologia da ESALQ/USP, no periodo de outubro/99 a abril/00.

Os híbridos comerciais XLX 520, Z 8452, C 909, P 3063, P 3081, AG 3010, FT 9006, FT 9043, DO 02 e D 766 foram utilizados por apresentarem niveis variados de resistência, quando avaliados sob condiçōes naturais de infecção. Sementes destes híbridos foram prégerminadas sobre duas folhas de papel umedecidas, contidas em bandejas plásticas, as quais foram cobertas com filme plástico transparente e colocadas em germinador a $25^{\circ} \mathrm{C}$, por 4 dias. Após a germinação efetuou-se o plantio em copos plásticos $(250 \mathrm{~mL})$, contendo uma mistura esterilizada de solo, areia e matéria orgânica, mantendo-se 1 planta/copo. Plantas com dez dias de idade, foram experimentalmente 
inoculadas com fitoplasma por meio de dez insetos infectivos por planta. Serviram de testemunhas, plantas infestadas com 10 insetos sadios por planta e plantas sem infestação de insetos. Durante a inoculação, os insetos permaneceram confinados sobre as plantas durante 4 dias, com o auxilio de gaiolas representadas por garrafas plásticas de 2L. Após o periodo de inoculação, as gaiolas e os insetos foram retirados $\mathrm{e}$ as plantas pulverizadas com inseticida sistêmico imidacloprid. Aos 30 dias após o plantio, as plantas foram transferidas para sacos plásticos $(5 \mathrm{~L})$ contendo o mesmo substrato descrito anteriormente, e receberam $12 \mathrm{~g}$ de uma mistura de sulfato de amônio e da fôrmula 4-14-8 (1:2), a cada intervalo de 21 dias. O delineamento experimental foi inteiramente casualizado, em esquema fatorial $10 \times 3$, com 3 repetições, sendo as parcelas representadas pelas repetições ( 1 planta).

A população infectiva de $D$. maidis foi obtida conforme a metodologia descrita por Nault (1980). Ninfas de $2^{\circ}$ e $3^{\circ}$ instares, criadas em plantas de milho sadias, foram mantidas junto ao cartucho de planta fonte de fitoplasma, o hibrido XL 333, durante 4 dias e, em seguida, transferidas para plantas sadias, nas quais foram mantidas por 21 dias, correspondente ao periodo de latência.

A avaliação do ensaio foi realizada por meio de observação semanal dos sintomas e, quando as plantas atingiram o estádio de grão pastoso, foi medida a altura das mesmas e foi feita a contagem do número de espigas/planta. Após a colheita, foram determinados o comprimento da espiga, o número de fileiras de grãos/espiga, o número de grãos por planta e a produção. O grau de umidade dos grãos foi padronizado através de secagem em estufa, a $105 \pm 2^{\circ} \mathrm{C}$, por $24 \mathrm{~h}$, corrigindo-se a produção de grãos $(\mathrm{g} / \mathrm{pl}$ ) para o teor de umidade de $12 \%$.

$O$ teste de retenção de grãos em peneiras foi realizado visando avaliar o tamanho dos grãos. Os grãos foram separados utilizando-se 
um conjunto oito peneiras de malhas circulares, cujos diâmetros decrescentes foram 9.52, 9.12, 8.73, 8.33, 7.93, 7.54, $7.14 \mathrm{e}<7.14 \mathrm{~mm}$ (fundo). Em seguida, foi determinada a porcentagem de grãos retidos em cada peneira, para cada um dos tratamentos.

A germinação das sementes foi avaliada através do teste padrāo de germinação, de acordo com as Regras para Análise de Sementes (Brasil, 1992). Foram tomadas ao acaso 50 sementes, distribuidas em duas folhas de papel de germinação e cobertas por uma terceira, sendo o conjunto enrolado. Os rolos identificados foram colocados num germinador a $25^{\circ} \mathrm{C}$ e a contagem de plântulas normais foi realizada aos 4 e 7 dias de incubação, determinando-se posteriormente a porcentagem de germinação.

As técnicas de PCR (polymerase chain reaction) e ELISA (enzyme-linked immunoabsorbent assay) foram aplicadas com a finalidade de se demonstrar a presença de fitoplasma e ausência de espiroplasma, respectivamente. Amostras foliares de alguns híbridos inoculados, coletadas no estádio de grão pastoso, foram submetidas a extração do DNA e, posteriormente, à amplificação das seqũências de 16S rDNA nas reações de PCR, conforme a metodologia descrita por Lee et al. (1993). O controle positivo foi representado pelo DNA extraído de amostras foliares da planta fonte e como controles negativos foram usados água e DNA proveniente de plantas sadias de milho. Os produtos de PCR foram analisados por eletroforese em gel de agarose a $1 \%$ e as bandas de DNA foram visualizadas num transluminador de luz ultravioleta.

Amostras foliares, de planta fonte $\mathrm{e}$ de alguns híbridos inoculados, foram coletadas e submetidas ao teste de PTA-ELISA com antissoro policlonal para Spiroplasma kunkelii, conforme a metodologia de Mowat \& Dawson (1987). Como controles positivo e negativo 
utilizaram-se folhas de plantas exibindo sintomas tipicos da infecção por espiroplasma e folhas sadias, respectivamente. A leitura foi feita 30 minutos após a adição do substrato, em aparelho para leitura de placas a $405 \mathrm{~nm}$. Foram consideradas positivas as amostras que apresentaram valores de absorbância no minimo duas vezes maior que o apresentado pelo controle negativo.

A análise estatística dos dados foi realizada por meio de programa SAS for Windows (SAS Institute, Cary, NC). Utilizou-se os dados originais obtidos para altura de plantas, comprimento de espigas e produção de grãos, sendo os dados obtidos para o número de espigas transformados $\mathrm{em} \sqrt{\mathrm{x}}+1$. Os dados foram analisados pelo teste Tukey ao nivel de $5 \%$ de probabilidade.

\subsection{RESULTADOS}

\subsubsection{Desenvolvimento de sintomas}

Os primeiros sintomas, caracterizados pelo desenvolvimento de clorose marginal e apical, seguido de avermelhamento, foram observados nas folhas, em oito dos dez híbridos avaliados, a partir de 30 dias após a inoculação. Plantas inoculadas dos híbridos P 3081, AG 3010, FT 9043, XLX 520, FT 9006, C 909, P 3063 e Z 8452 apresentaram reaçōes semelhantes quanto ao avermelhamento, havendo, no entanto, variação na intensidade. Este sintoma se manifestou inicialmente nas folhas mais velhas e, em seguida, nas folhas mais jovens, 'a medida em que eram emitidas pelas plantas. Plantas testemunhas não exibiram os sintomas expressos pelas plantas infectadas pelo fitoplasma. 
Combinações entre os sintomas de enfezamento, encurtamento de entrenôs, brotaçōes axilares, perfilhamento, folhas retorcidas e proliferação de espigas anormais foram observadas, de maneira geral, em todos os híbridos, durante o desenvolvimento das plantas inoculadas (Figura 4A). Os hỉbridos D 766 e DO 02 apresentaram reaçāo diversa em relação aos demais, não desenvolvendo avermelhamento nas folhas, mas sim áreas de coloração parda (Figura 4B). Sintomas menos severos de enfezamento foram observados em plantas pertencentes aos hibridos FT 9006, Z 8452, P 3063, D 766 e FT 9043. 

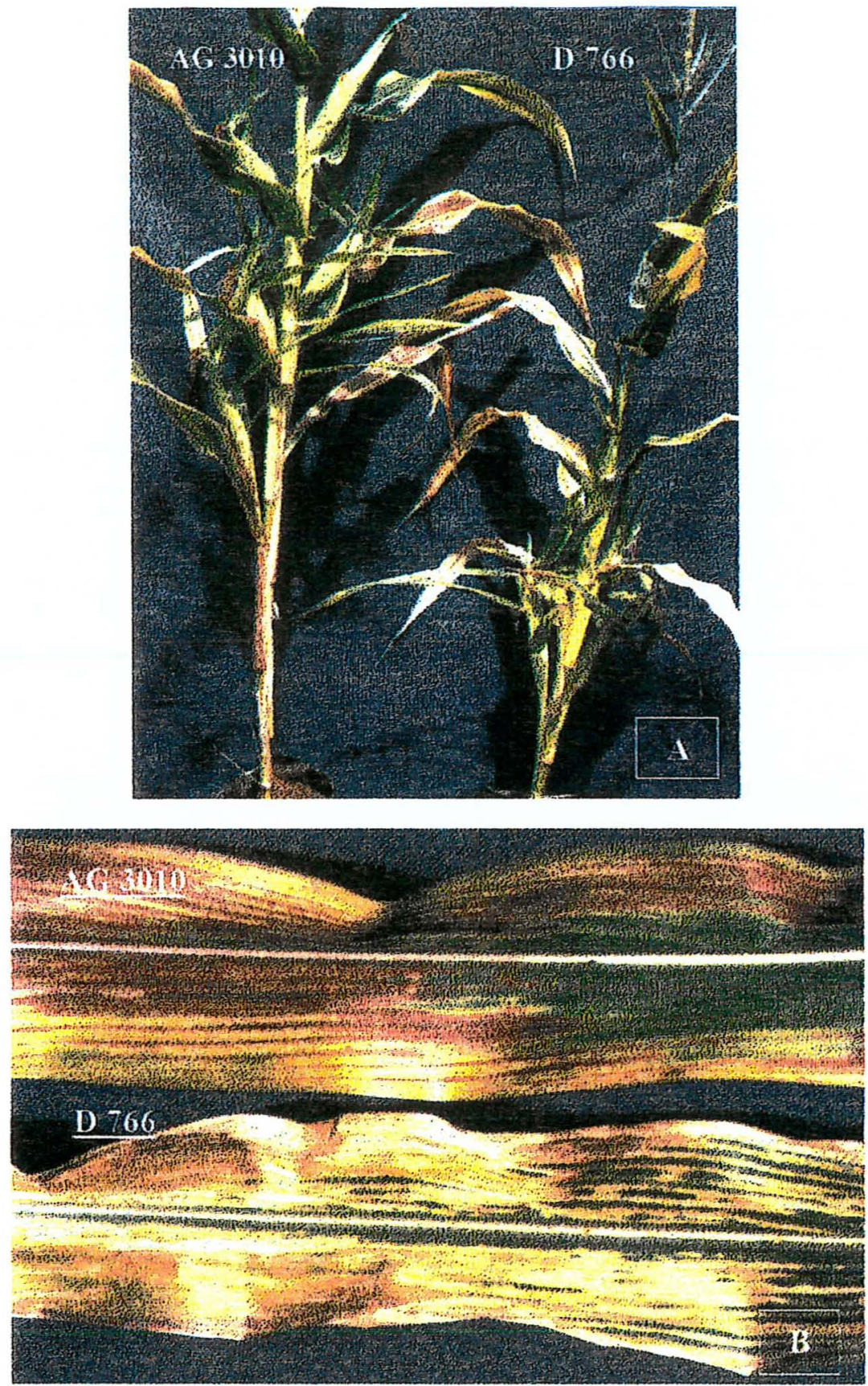

Figura 4. Sintomas mostrados por plantas, de diferentes híbridos, inoculadas com o fitoplasma do enfezamento através de dez insetos infectivos/planta. A) avermelhamento foliar e brotações axilares; B) estrias de coloração vermelha e parda. 


\subsubsection{Danos causados pelo enfezamento vermelho}

Com base na análise de variância dos dados (Tabela 3), verificou-se que a altura de plantas inoculadas foi significativamente menor nos híbridos C 909, P 3081, DO 02, AG 3010 e XLX 520, sendo que as plantas afetadas apresentaram uma redução média de $35 \%$, quando comparadas com as plantas testemunhas livres de insetos. Para os demais híbridos, houve uma tendência das plantas inoculadas apresentarem redução de altura, em relação às plantas testemunhas.

As avaliaçōes mostraram que a produção de grãos por plantas inoculadas também foi reduzida de maneira significativa (Tabela 3). Os valores médios de redução foram de $70,73,79$, e $98 \%$ para os híbridos P 3081, P 3063, C 909 e XLX 520, respectivamente, quando comparados com as plantas testemunhas livres de insetos. Um efeito negativo do patógeno sobre o rendimento de grãos foi constatado para os demais híbridos, embora esta diferença não tenha sido detectada pela análise estatística. Não foi constatada diferença significativa entre a produção de plantas testemunhas infestadas por insetos sadios e de plantas não submetidas à alimentação de insetos.

O número de espigas anormais, caracterizadas por apresentarem tamanho pequeno e grãos miúdos, foi significativamente maior nas plantas inoculadas (Tabela 4). Assim, os híbridos C 909, AG 3010, FT 9006, FT 9043, P 3063, D 766 apresentaram em média, 3.6, $3.8,4.2,5.0,5.2$ e 5.3 espigas/planta, enquanto os hibridos $\mathrm{P} 3081$, DO 02 e $Z 8452$ produziram, em média, 2 espigas/planta. A maioria das plantas pertencentes ao híbrido XLX 520 não chegou a produzir espigas. Plantas testemunhas, independentemente de terem ou não sido submetidas à população de insetos sadios, produziram normalmente suas espigas. 
Tabela 3.Efeito do fitoplasma do enfezamento vermelho sobre a altura e produção de grãos por plantas de milho, de diferentes híbridos, inoculadas através de dez insetos infectivos/planta.

\begin{tabular}{|c|c|c|c|c|}
\hline \multirow[t]{2}{*}{ Híbridos } & \multirow[t]{2}{*}{ Vetor } & \multirow{2}{*}{$\begin{array}{l}\text { Altura } \\
\text { (m) }\end{array}$} & \multicolumn{2}{|c|}{ Produção de grãos } \\
\hline & & & $\mathrm{g} / \mathrm{pl}$ & Taxa de redução \\
\hline \multirow{3}{*}{ P 3081} & Infectivo & $1.34 \mathrm{a}$ & $27.41 \mathrm{a}$ & $70.11 \%$ \\
\hline & Sadio & $1.97 \mathrm{ab}$ & $87.06 \mathrm{ab}$ & \\
\hline & Ausente & $2.05 \mathrm{~b}$ & $91.71 \mathrm{~b}$ & \\
\hline \multirow{3}{*}{ DO 02} & Infectivo & $1.80 \mathrm{a}$ & $10.86 \mathrm{a}$ & $73.90 \%$ \\
\hline & Sadio & $2.50 \mathrm{~b}$ & $72.87 \mathrm{a}$ & \\
\hline & Ausente & $2.74 \mathrm{~b}$ & $41.61 \mathrm{a}$ & \\
\hline \multirow{3}{*}{ P 3063} & Infectivo & $1.68 \mathrm{a}$ & $32.13 \mathrm{a}$ & $73.29 \%$ \\
\hline & Sadio & $2.36 \mathrm{~b}$ & $117.69 \mathrm{~b}$ & \\
\hline & Ausente & $2.17 \mathrm{ab}$ & $120.33 \mathrm{~b}$ & \\
\hline \multirow{3}{*}{ D 766} & Infectivo & $1.34 \mathrm{a}$ & $20.53 a$ & $70.94 \%$ \\
\hline & Sadio & $2.26 \mathrm{~b}$ & $109.04 \mathrm{~b}$ & \\
\hline & Ausente & $1.80 \mathrm{ab}$ & $70.67 \mathrm{ab}$ & \\
\hline \multirow{3}{*}{ XLX 520} & Infectivo & $1.59 \mathrm{a}$ & $1.39 \mathrm{a}$ & $98.31 \%$ \\
\hline & Sadio & $2.41 \mathrm{~b}$ & $103.4 \mathrm{~b}$ & \\
\hline & Ausente & $2.37 \mathrm{~b}$ & $82.37 \mathrm{~b}$ & \\
\hline \multirow{3}{*}{ AG 3010} & Infectivo & $1.40 \mathrm{a}$ & $37.55 \mathrm{a}$ & $54.73 \%$ \\
\hline & Sadio & $2.24 \mathrm{~b}$ & $99.41 \mathrm{a}$ & \\
\hline & Ausente & $2.12 \mathrm{~b}$ & $82.96 \mathrm{a}$ & \\
\hline \multirow{3}{*}{ Z 8452} & Infectivo & $2.09 \mathrm{a}$ & $35.91 \mathrm{a}$ & $59.53 \%$ \\
\hline & Sadio & $2.24 \mathrm{a}$ & $99.83 \mathrm{~b}$ & \\
\hline & Ausente & $2.25 \mathrm{a}$ & $88.75 \mathrm{ab}$ & \\
\hline \multirow{3}{*}{ FT 9006} & Infectivo & $1.63 \mathrm{a}$ & $49.17 \mathrm{a}$ & $35.67 \%$ \\
\hline & Sadio & $1.90 \mathrm{a}$ & $97.48 \mathrm{a}$ & \\
\hline & Ausente & $1.89 \mathrm{a}$ & $76.44 \mathrm{a}$ & \\
\hline \multirow{3}{*}{ FT 9043} & Infectivo & $1.47 \mathrm{a}$ & $40.45 \mathrm{a}$ & $57.10 \%$ \\
\hline & Sadio & $1.87 \mathrm{a}$ & $103.20 \mathrm{a}$ & \\
\hline & Ausente & $2.07 \mathrm{a}$ & $94.31 \mathrm{a}$ & \\
\hline \multirow{3}{*}{ C 909} & Infectivo & $1.24 \mathrm{a}$ & $16.06 \mathrm{a}$ & $79.65 \%$ \\
\hline & Sadio & $2.11 \mathrm{~b}$ & $86.36 \mathrm{~b}$ & \\
\hline & Ausente & $1.97 \mathrm{~b}$ & $78.92 \mathrm{~b}$ & \\
\hline $\mathrm{CV} \%$ & & 9.60 & 29.10 & \\
\hline
\end{tabular}

Médias seguidas pelas mesmas letras na mesma coluna, dentro de cada híbrido, não diferem entre si pelo teste Tukey ao nível de $5 \%$ de probabilidade. 
O tamanho das espigas produzidas por plantas inoculadas foi significativamente menor do que aquelas produzidas pelas plantas testemunhas, para todos os híbridos avaliados (Tabela 4). A redução do tamanho variou de 52.5 a $72.5 \%$, ou seja, as espigas anormais corresponderam à metade ou até $1 / 4$ do tamanho de uma espiga normal. Plantas não inoculadas apresentaram espigas de tamanho normal, variando de 12 a $16 \mathrm{~cm}$, de acordo com o híbrido, nas condiçōes do ensaio.

O número de fileiras de grãos/espiga foi variável entre os híbridos inoculados. Assim, uma redução média de $15 \%$ foi constatada para os híbridos P 3081, DO 02, AG 3010, Z 8452 e C 909. Espigas dos hibridos D 766, FT 9006 e FT 9043 formaram somente $2 / 3$ do número total de fileiras presentes nas espigas normais, as quais produziram de 10-12 fileiras. As reduçōes mais severas foram observadas nos híbridos P 3063 e XLX 520, os quais apresentaram 50\% e $20 \%$ do número de fileiras presentes nas espigas normais, respectivamente.

O número de grãos/planta variou dentro de uma faixa ampla, em função do híbrido e da inoculação das plantas. As alterações provocadas pelo fitoplasma foram bastante variáveis entre os híbridos, sendo os valores extremos encontrados nos híbridos FT 9006 e XLX 520, para os quais foram registradas reduções de 5 e $98 \%$, respectivamente. Reduçōes em torno de $50 \%$ foram constatadas para os hibridos Z 8452, P 3063 e DO 02, quando foram comparadas plantas inoculadas e testemunhas nāo submetidas a alimentação de insetos. 
Tabela 4. Efeito do fitoplasma do enfezamento vermelho sobre o número e tamanho de espigas produzidas por plantas de milho, de diferentes hibridos, inoculadas através de dez insetos infectivos/planta.

\begin{tabular}{|c|c|c|c|}
\hline Híbridos & Vetor & $\begin{array}{c}\text { Número de } \\
\text { espigas }\end{array}$ & $\begin{array}{l}\text { Tamanho de } \\
\text { espigas }(\mathrm{cm})\end{array}$ \\
\hline \multirow{3}{*}{ P 3081} & Infectivo & $2.6 \mathrm{a}$ & $5.35 \mathrm{a}$ \\
\hline & Sadio & $1.0 \mathrm{a}$ & $12.90 \mathrm{~b}$ \\
\hline & Ausente & $1.0 \mathrm{a}$ & $14.53 \mathrm{~b}$ \\
\hline \multirow{3}{*}{ DO 02} & Infectivo & $1.6 \mathrm{a}$ & $6.76 \mathrm{a}$ \\
\hline & Sadio & $1.0 \mathrm{a}$ & $15.96 \mathrm{~b}$ \\
\hline & Ausente & $1.0 \mathrm{a}$ & $14.23 \mathrm{~b}$ \\
\hline \multirow{3}{*}{ P 3063} & Infectivo & $5.2 \mathrm{a}$ & $4.61 \mathrm{a}$ \\
\hline & Sadio & $1.0 \mathrm{~b}$ & $15.65 \mathrm{~b}$ \\
\hline & Ausente & $1.0 \mathrm{~b}$ & $15.90 \mathrm{~b}$ \\
\hline \multirow{3}{*}{ D 766} & Infectivo & $5.3 \mathrm{a}$ & $4.22 \mathrm{a}$ \\
\hline & Sadio & $1.0 \mathrm{~b}$ & $15.86 \mathrm{~b}$ \\
\hline & Ausente & $1.0 \mathrm{~b}$ & $12.80 \mathrm{~b}$ \\
\hline \multirow{3}{*}{ XLX 520} & Infectivo & $0.3 a$ & $1.30 \mathrm{a}$ \\
\hline & Sadio & $1.0 \mathrm{a}$ & $14.23 \mathrm{~b}$ \\
\hline & Ausente & $1.0 \mathrm{a}$ & $12.13 \mathrm{~b}$ \\
\hline \multirow{3}{*}{ AG 3010} & Infectivo & $3.8 \mathrm{a}$ & $5.29 \mathrm{a}$ \\
\hline & Sadio & $1.0 \mathrm{~b}$ & $13.93 \mathrm{~b}$ \\
\hline & Ausente & $1.0 \mathrm{~b}$ & $13.43 \mathrm{~b}$ \\
\hline \multirow{3}{*}{ Z 8452} & Infectivo & $1.9 \mathrm{a}$ & $8.10 \mathrm{a}$ \\
\hline & Sadio & $1.0 \mathrm{a}$ & $16.00 \mathrm{~b}$ \\
\hline & Ausente & $1.0 \mathrm{a}$ & $17.26 \mathrm{~b}$ \\
\hline \multirow{3}{*}{ FT 9006} & Infectivo & $4.2 \mathrm{a}$ & $6.67 a$ \\
\hline & Sadio & $1.0 \mathrm{~b}$ & $16.85 \mathrm{~b}$ \\
\hline & Ausente & $1.0 \mathrm{~b}$ & $15.63 \mathrm{~b}$ \\
\hline \multirow{3}{*}{ FT 9043} & Infectivo & $5.0 \mathrm{a}$ & $4.56 \mathrm{a}$ \\
\hline & Sadio & $1.0 \mathrm{~b}$ & $16.00 \mathrm{~b}$ \\
\hline & Ausente & $1.0 \mathrm{~b}$ & $16.60 \mathrm{~b}$ \\
\hline \multirow{3}{*}{ C 909} & Infectivo & $3.6 \mathrm{a}$ & $4.61 \mathrm{a}$ \\
\hline & Sadio & $1.0 \mathrm{~b}$ & $15.06 \mathrm{~b}$ \\
\hline & Ausente & $1.0 \mathrm{~b}$ & $12.53 \mathrm{~b}$ \\
\hline CV \% & & 11.34 & 16.25 \\
\hline
\end{tabular}

Médias seguidas pelas mesmas letras na coluna, dentro de cada híbrido, não diferem entre si pelo teste de Tukey a $5 \%$ de probabilidade. 


\subsubsection{Teste de retenção de grãos em peneiras}

O teste de retenção de grãos em peneiras evidenciou uma predominância absoluta de grãos miúdos originários de plantas inoculadas. Considerando-se todos os híbridos, $92 \%$ dos grãos produzidos por plantas infectadas passaram ou ficaram retidos na peneira de menor malha $(7,14 \mathrm{~mm})$ (Figura 5). Por outro lado, ainda considerando uma média de todos os híbridos, somente $14 \%$ dos grãos provenientes de plantas testemunhas, livres de insetos, foram retidos ou passaram por esta peneira.

\subsubsection{Teste de germinação de sementes}

A germinação de sementes, de modo geral, foi afetada negativamente pela presença de fitoplasma na planta. Reduções de 18 , 16,14 e $12 \%$ foram registradas para os hibridos P 3063, C 909, XLX 520 e AG 3010, respectivamente. Deve ser ressaltado, no entanto, que para os demais hibridos, a porcentagem de germinação foi semelhante entre sementes produzidas por plantas inoculadas e sadias.

\subsubsection{Testes de PCR e ELISA}

Através do teste de PCR foi confirmada a presença de fitoplasma na planta fonte e naquelas sintomáticas que foram amostradas durante a condução do ensaio. $O$ teste de ELISA demonstrou a ausência de espiroplasma nestas mesmas plantas. 

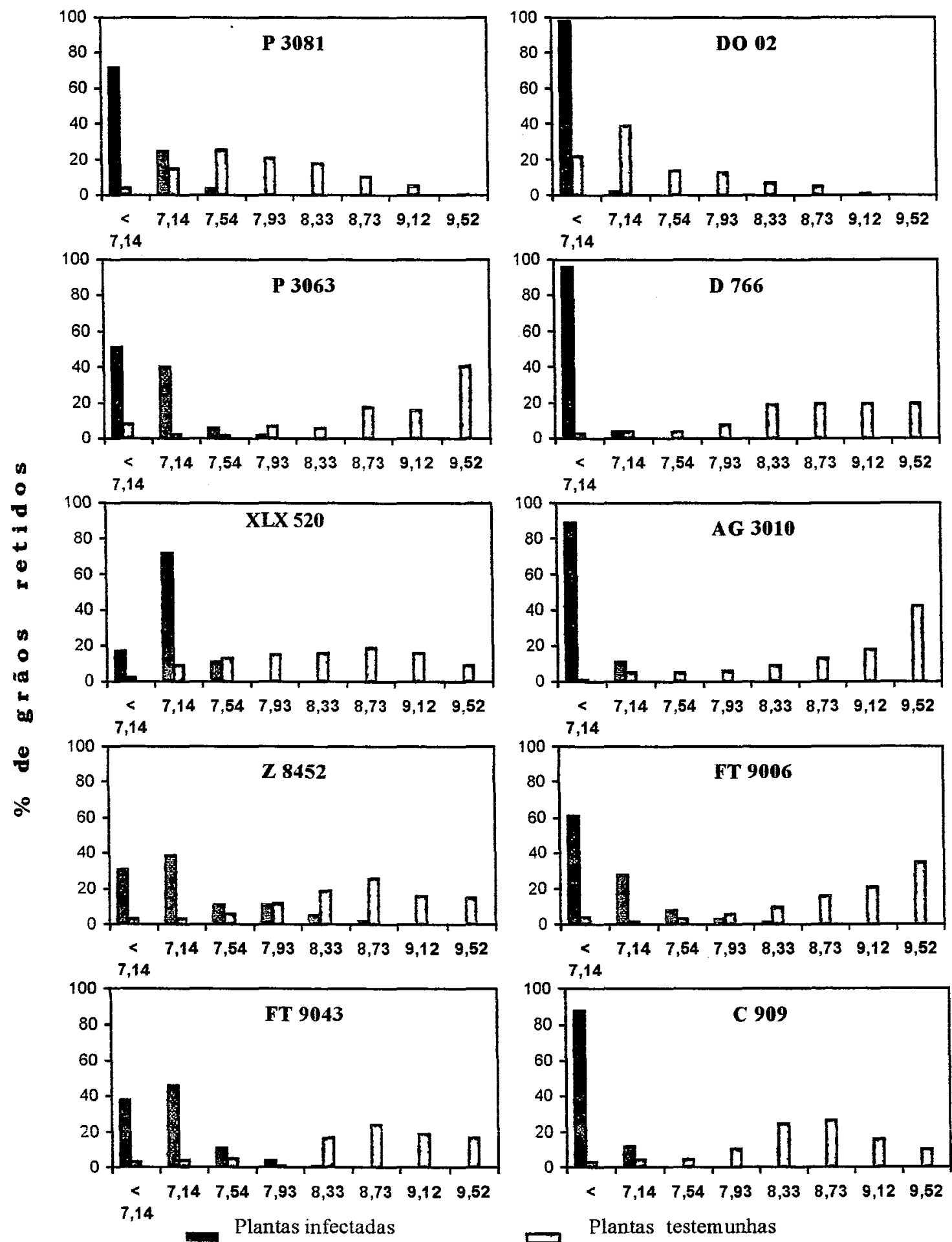

$\square$ Plantas testemunhas

Figura 5. Efeito da infecção do fitoplasma do enfezamento sobre o tamanho dos grãos de hibridos comerciais, avaliado através de um conjunto de peneiras de malhas circulares de 7.14 a $9.52 \mathrm{~mm}$. 


\subsection{DISCUSSĀo}

O avermelhamento foliar foi o sintoma mais evidente na maioria dos hibridos inoculados, indicando que este sintoma está predominantemente associado à presença de fitoplasma em plantas de milho. Esta associação, relatada em outros artigos, confirma os resultados obtidos neste trabalho (Bedendo, 1999; Nault, 1980; Oliveira et al., 1998). Vale ressaltar, entretanto, que embora o avermelhamento predomine em plantas infectadas por fitoplasma, o mesmo pode estar associado também a espiroplasma, nāo sendo, portanto, um sintoma típico para a diagnose de enfezamento vermelho (Bajet \& Renfro, 1989; Massola Júnior et al., 1999a; Nault, 1980). O aparecimento de áreas pardas, em lugar do avermelhamento, em folhas de dois dos hibridos inoculados com fitoplasma, não se constituiu em novidade, pois de acordo com Nault (1980) uma variaçāo de sintomas pode ocorrer em função do genótipo e do ambiente. Os demais sintomas observados nas plantas inoculadas, como encurtamento de entrenós, brotaçōes e proliferação de espigas também podem ser causados tanto por fitoplasma como por espiroplasma e podem se manifestar com maior ou menor intensidade dependendo de fatores diversos como suscetibilidade e estâdio fenológico do hospedeiro, condições de ambiente e população de vetor, entre outros (Bedendo, 1997; Bedendo, 1999; Massola Júnior et al., 1999c; Nault, 1980; Oliveira et al., 1998). Estes resultados reforçam a sugestão de Davis (1995), de que a diagnose com base nos sintomas deve ser confirmada através da detecção destes molicutes no tecido de plantas sintomáticas.

A redução na altura das plantas, em função do encurtamento de entrenós, tem sido freqūentemente observada em plantas infectadas por fitoplasma (Bedendo, 1999; Hruska \& Peralta, 1997; Shurtleff, 
1986). Nas condições do ensaio, para alguns híbridos, foi bastante visivel a diferença entre plantas inoculadas e não inoculadas. No entanto, nestas mesmas condições, não se constatou redução na altura de plantas inoculadas para determinados hibridos, evidenciando a ocorrência de variação entre híbridos quanto à expressão deste sintoma. Este mesmo tipo de observação tem sido relatada por diversos pesquisadores, tanto em materiais colocados no campo, como naqueles estudados sob condições controladas (Hruska \& Peralta, 1997; Massola Júnior et al., 1999b; Nault, 1980; Oliveira et al., 1998). Assim, a presença de fitoplasma pode implicar ou não em redução da altura da planta, dependendo do genótipo do material de milho.

A produção de grãos foi afetada negativamente em plantas inoculadas, porém os valores de produção foram variáveis dependendo do híbrido considerado. Um dos híbridos praticamente não produziu grāos, um grupo deles teve sua produçāo drasticamente reduzida e outro grupo apresentou produção semelhante às plantas testemunhas. A importância da doença para a cultura do milho está justamente relacionada com os danos relevantes decorrentes da infecção pelo patógeno. Perdas na produção têm sido freqūentemente constatadas em áreas cultivadas com milho, atingido normalmente valores médios acima de $50 \%$, porém a produção pode ser nula em função do genótipo da planta, da época de infecção e da população do vetor (Hruska \& Peralta, 1997; Oliveira et al., 1998; Scott et al., 1977). Os resultados relatados por estes autores confirmam aqueles obtidos no presente trabalho, os quais demonstraram que a presença de fitoplasma pode levar a um sério comprometimento da produção.

A proliferação de espigas mal formadas é uma caracteristica comum em plantas portadoras de fitoplasma (Bedendo, 1999; Nault, 1980; Oliveira et al., 1998; Scott et al., 1977). Portanto, foi justificável a 
ocorrência desta anomalia em praticamente todos os híbridos inoculados, inclusive a proliferação mais acentuada em alguns dos híbridos. O fato do híbrido XLX 520 não ter produzido espiga pode ser uma evidência da alta suscetibilidade deste material. Juntamente com o avermelhamento, a formaçāo de espigas extranumerárias é um sintoma bastante evidente, sendo útil na diagnose da doença. No entanto, este sintoma também pode ser causado por espiroplasma (Bedendo, 1997; Massola Júnior et al., 1999c; Nault, 1980) não servindo como parâmetro único para identificaçāo de doença associada ao fitoplasma.

Redução no tamanho das espigas foi constatada, indistintamente, para todos os híbridos inoculados, embora o grau de redução tenha sido mais drástico para alguns dos híbridos. Esse tipo de alteração tem sido relatada por outros autores através de observações visuais, sem, no entanto, ter sido dimensionada esta redução (Hruska \& Peralta, 1997; Oliveira et al., 1998). No presente trabalho ficou demonstrado esta redução, sendo que as espigas anormais apresentaram tamanho correspondente à metade ou até a $1 / 4$ de uma espiga normal. O número de fileiras/espiga e número de grãos/planta também foram afetados negativamente em maior ou menor grau, dependendo do híbrido considerado. Apesar da suposição inicial de que quanto menor a espiga menor o número de fileiras e o número de grãos, não foi possivel estabelecer uma correlação entre estes três parâmetros. Assim, híbridos que apresentaram espigas de tamanho semelhantes, mostraram disparidade relevante quanto aos dois outros parâmetros avaliados. Por outro lado, hibridos que produziram espigas de tamanho diferenciado, mostraram semelhança para fileiras e/ou número de grãos.

A predominância de grãos miúdos produzidos pelos hibridos inoculados evidenciou o efeito altamente prejudicial do fitoplasma sobre 
a produção. Assim, 92\% dos grãos produzidos por plantas inoculadas ficaram retidos ou passaram pela peneira de menor malha contra apenas $14 \%$ dos grãos originários de testemunhas. A redução no tamanho de grãos tem sido uma das características observadas para plantas infectadas tanto para fitoplasma como para espiroplasma (Nault, 1980; Oliveira et al., 1998). O efeito isolado de espiroplasma sobre o tamanho de grãos foi avaliado por Massola Júnior e colaboradores (1999a), os quais constataram que quase a totalidade dos grãos produzidos por plantas inoculadas foram retidos na peneira de menor malha, de forma idêntica àquela encontrada neste ensaio realizado com fitoplasma. A redução na qualidade pode justificar as menores porcentagens de germinação, quando se compara os grãos produzidos a partir de plantas testemunhas e com plantas infectadas por fitoplasma.

A incidência dos enfezamentos nas culturas de milho instaladas no território brasileiro tem sido alta, resultando em perdas relevantes. A grande maioria dos híbridos avaliados tem se mostrado suscetivel. No campo, fitoplasma e espiroplasma ocorrem formando um complexo, cujos sintomas e efeitos isolados de cada patógeno são dificeis de serem separados. Utilizando dois híbridos, Massola Júnior e colaboradores (1999a) demonstraram os danos causados pelo espiroplasma atuando isoladamente. No presente trabalho ficou evidenciado o efeito isolado do fitoplasma, em relação à sintomatologia $\mathbf{e}$ sobre os diferentes componentes de produção. Assim, a soma de esforços vem contribuindo para um maior conhecimento sobre estas doenças, com o objetivo de mostrar sua real importância para a cultura do milho e de fornecer subsidios para o seu controle. 


\section{CONCLUSÕES}

- Os sintomas predominantes causados pelo fitoplasma foram enfezamento, avermelhamento foliar e proliferação de espigas.

- Variação da coloração vermelha para parda pode ocorrer dependendo do genótipo do hospedeiro.

- A severidade dos sintomas foi diretamente proporcional ao número de insetos utilizados para inoculação do fitoplasma.

- A incidência da doença aumentou à medida em que se aumentou o número de vetores infectivos.

- A produção de grãos foi reduzida em plantas inoculadas, sendo inversamente proporcional ao número de insetos infectivos.

- Os hibridos apresentaram variação quanto à reação à doença, porém todos podem ser considerados suscetiveis.

- Em razão dos danos causados, o enfezamento vermelho mostrou ser uma doença altamente destrutiva para o milho. 


\section{REFERÊNCIAS BIBLIOGRÁFICAS}

BAJET, N.B.; RENFRO, B.L. Occurrence of corn stunt spiroplasma at different elevations in Mexico. Plant Disease, v.73, n.11, p.926-930, 1989.

BALMER, E.; PEREIRA, O.A.P. Doenças do milho. In: PATERNIANI, E.; ORIEGAS, G.P. (Ed.) Melhoramento e produção de milho. Campinas: Fundação Cargill, 1987. cap.14, p.597-634.

BEDENDO, I.P. Espiroplasmas patogênicos a plantas. Revisão Anual de Patologia de Plantas, v.5, p.99-131, 1997.

BEDENDO, I.P. Enfezamento vermelho e enfezamento pálido do milho associados a fitoplasma e espiroplasma: sintomatologia, etiologia $\mathrm{e}$ técnicas para deteç̧ão e identificação destes agentes. Summa Phytopathologica, v.25, n.3, p.190-196, 1999.

BEDENDO, I.P.; DAVIS, R.E.; DALLY, E.L. Detection and identification of the maize bushy stunt phytoplasma in corn plants in Brazil using PCR and RFLP. International Journal of Pest Management, v.46, n.1, p.73-76, 2000. 
BHIRUD, K.M.; PITRE, H.N. Bioactivity of systemic insecticides in corn: relationships to leafhopper vector control and corn stunt disease incidence. Journal of Economic Entomology, v.65, n.4, p.1134$1140,1972$.

BORGES, R.T.P.B. Método de seleção em milho para resistência da risca-fitoplasma-espiroplasma. Piracicaba, 1997. 58p. Tese (Doutorado) - Escola Superior de Agricultura "Luiz de Queiroz", Universidade de São Paulo.

BRASIL. Ministério da Agricultura e Reforma Agrária. Regras para análise de sementes. Brasília, 1992. 365p.

BUSHING, R.W.; BURTON, V.E. Leafhopper damage to silage corn in California. Journal of Economic Entomology, v.67, n.5, p.656-658, 1974.

CHEN, T.A.; JIANG, X.F. Monoclonal antibodies against the maize bushy stunt disease agent. Canadian Journal of Microbiology, v.34, p.6$11,1988$.

COSTA, A.S.; KITAJIMA, E.W.; ARRUDA, S.C. Moléstia de virus e de micoplasma do milho em São Paulo. Revista da Sociedade Brasileira de Fitopatologia, v.4, n.4, p.39-41, 1971.

DAVIS, R.E. Fitoplasmas: fitopatógenos procarióticos sem parede celular, habitantes de floema e transmitidos por artrópodes. Revisão Anual de Patologia de Plantas, v.3, p.1-27, 1995. 
DAVIS, R.E.; LEE, I.M. Mycoplasmalike organisms as plant disease agents - a review. ATCC Quaterly Newsletter, v.2, n.4, p.7-10, 1991.

DUDIENAS, C.; DUARTE, A.P.; PATERNIANI, M.E.; RIBEIRO, J.L.; BIANCHINI, M.T.; KANTHACH, R.A.; CASTRO, J.L.; SILVEIRA, L.C.; DENUCCI, S.; SABINO JÜNIOR, J.; BOLONHESI, D.; DE SORDI, G. Severidade de doenças no milho "safrinha" no Estado de São Paulo em 1996. In: SEMINÁRIO SOBRE A CULTURA DO MILHO "SAFRINHA", 4., Assis, 1997. Anais. Assis: IAC; CDV, 1997. p.107115.

FANCELLI, A.L.; LIMA, U.A. Milho: produção, pré-processamento e transformação agroindustrial. Piracicaba: Coordenadoria da Indústria e do Comércio; FEALQ, 1992. 112p. (Série Extensão Agroindustrial, 5).

FOLEGATTI, M.E.G.; LOPES, J.R.S.; ESTEVES, A.A.; CATO, S.C. Incidência de enfezamento do milho e população do vetor, Dalbulus maidis (Hemiptera, Cicadellidae) em cinco épocas de plantio em Piracicaba (SP). In: CONGRESSO BRASILEIRO DE ENTOMOLOGIA, 16., Salvador, 1997. Resumos. Salvador: SEB, 1997a. p.361.

FOLEGATTI, M.E.G.; LOPES, J.R.S.; AMORIM, L.; SILVA, W.J.; SOLFERINO, O.B.; SILVA, H.P.; PEREIRA, O.A.P. Incidência de enfezamento do milho e população do vetor, Dalbulus maidis, em diferentes localidades e épocas de plantio, na safra 95/96. Fitopatologia Brasileira, v.22, p.347, 1997b. 
GUNDERSEN, D.E.; LEE, I.M.; REHNER, S.A.; DAVIS, R.E.; KINGSBURY, D.T. Phylogeny of mycoplasmalike organisms (phytoplasmas) a basis for their classification. Journal of Bacteriology, v.176, n.17, p.5244-5254, 1994.

GUNDERSEN, D.E.; LEE, I.M.; SCHAFF, D.A.; HARRINSON, N.A.; CHANG, C.J.; DAVIS, R.E.; KINGSBURY, D.T. Genomic diversity and differentiation among phytoplasmas strains in 16S rRNA groups I (aster yellows and related phytoplasmas) and III (X-disease and related phytoplasmas). International Journal of Systematic Bacteriology, v.46, n.1, p.64-75, 1996.

HARRISON, N.A.; RICHARDSON, P.A.; TSAI, J.H. PCR assay for detection of the phytoplasma associated with maize bushy stunt disease. Plant Disease, v.80, n.3, p.263-269, 1996.

HRUSKA, A.J.; PERALTA, M.G. Maize response to corn leafhopper (Homoptera: Cicadellidae) infestation and achaparramiento disease. Journal of Economic Entomology, v.90, n.2, p.604-610, 1997.

HRUSKA, A.J.; GLADSTONE, S.M.; OBANDO, R. Epidemic roller coaster: maize stunt disease in Nicaragua. American Entomologist, v.42, n.4, p.248-252, 1996.

KITAJIMA, E.W. Enfermidades de plantas associadas a organismos do tipo micoplasma. Revisão Anual de Patologia de Plantas, v.2, p.153-174, 1994. 
KITAJIMA, E.W.; COSTA, A.S. Microscopia electrônica de microrganismos do tipo micoplasma nos tecidos de milho afetado pelo enfezamento e nos órgãos da cigarrinha vectora portadora. Bragantia, v.31, n.6, p.75-82, 1972.

LEE, I.M.; DAVIS, R.E. Mycoplasmas which infect plants and insects. In: MANILOFF, J.; McELHANEY, R.N.; FINCH, L.R.; BASEMAN, J.B. Mycoplasmas: molecular biology and pathogenesi. Washington: American Society for Microbiology, 1992. cap.23, p.379-390.

LEE, I.M.; GUNDERSEN, D.E.; DAVIS, R.E.; BARTOSZYK, I.M. Revised classification scheme of phytoplasmas based on RFLP analysis of 16S rRNA and ribossomal protein gene sequences. International Journal of Systemic Bacteriology, v.48, p.1153-1169, 1998.

LEE, I.M.; HAMMOND, R.W.; DAVIS, R.E.; GUNDERSEN, D.E. Universal amplification and analysis of pathogen 16S rDNA for classification and identification of mycoplasmalike organism. Phytopathology, v.83, n.8, p.834-842, 1993.

LEGRAND, A.I.; POWER, A.G. Inoculation and acquisition of maize bushy stunt mycoplasma by its leafhopper vector Dalbulus maidis. Annals of Applied Biology, v.125, p.115-122, 1994.

LOPES, M.T.V.C.; CAMARGO, L.E.A.; FOLEGATTI, M.E.G.; LOPES, J.R.S. Freqüência de Mollicutes associados ao enfezamento do milho em algumas localidades do Estado de São Paulo. Fitopatologia Brasileira, v.22, p.347, 1997. 
MADDEN, L.V.; NAULT, L.R. Differential pathogenicity of corn stunting mollicutes to leafhopper vectors in Dalbulus and Baldulus species. Phytopathology, v.73, n.12, p.1608-1614, 1983.

MARAMOROSCH, K. The occurrence of two distinct types of corn stunt in Mexico. Plant Disease Reporter, St. Paul, v.39, p.896-898, 1955.

MARIN, R. Biologia y comportamiento de Dalbulus maidis (Homoptera: Cicadellidae). Revista Peruana de Entomologia, v.30, p.113-117, 1987.

MASSOLA JÚNIOR, N.S.; BEDENDO, I.P.; AMORIM, L.; LOPES, J.R.S. Danos provocados pelo complexo do enfezamento na cultura do milho. In: SEMINÁRIO SOBRE A CULTURA DO MILHO "SAFRINHA" 4., Assis, 1997. Anais. Assis: IAC; CDV, 1997. p.95-99.

MASSOLA JÚNIOR, N.S.; BEDENDO, I.P.; AMORIM, L.; LOPES, J.R.S. Efeito da inoculação de espiroplasma e fitoplasma sobre o crescimento e a produção de plantas de milho. In: CONGRESSO PAUlista DE FITOPATOLOGIA, 21., Botucatu, 1998. Resumos. Botucatu: SBF, 1998. p. 54.

MASSOLA JÜNIOR, N.S.; BEDENDO, I.P.; AMORIM, L.; LOPES, J.R.S. Effects of the inoculation time on corn with Spiroplasma kunkelii on yield components. Fitopatologia Brasileira, v.24, n.4, p.570-573, 1999a. 
MASSOLA JÚNIOR, N.S.; BEDENDO, I.P.; AMORIM, L.; LOPES, J.R.S. Fitoplasma e espiroplasma em milho: multiplicação e efeito na produção de genótipos resistente e suscetivel. Summa Phytopathologica, v. 25, n.4, p. 356-359, 1999 b.

MASSOLA JÚNIOR, N.S.; BEDENDO, I.P.; AMORIM, L.; LOPES, J.R.S. Quantificação de danos causados pelo enfezamento vermelho e enfezamento pálido do milho em condições de campo. Fitopatologia Brasileira, v.24, n.2, p.136-142, 1999c.

MOWAT, W.P.; DAWSON, S. Detection of plant viruses by ELISA using crude sap extracts and unfractioned antisera. Journal of Virological Methods, v. 15, p. 233-247, 1987.

MOYA-RAYGOZA, G.; NAULT, L.R. Transmission biology of mayze bushy stunt phytoplasma by the corn leafhopper (Homoptera: Cicadellidae). Annals of the Entomological Society of America, v.91, n.5, p.668676, 1998.

NAMBA, S.; KATO, S.; IWANAMI, S.; OYAIZU, H.; SHIOZAWA, H.; TSUCHIAZAKI, T. Detection and differentiation of plant pathogenic mycoplasmalike organisms using polymerase chain reaction. Phytopathology, v.83, n.7, p.786-791, 1993.

NAULT, L.R. Maize bushy stunt and corn stunt: a comparison of disease symptoms, pathogen host ranges, and vectors. Phytopathology, v.70, n.7, p.659-662, 1980. 
NAULT, L.R. Evolution of an insect pest: maize and the corn leafhopper, a case study. Maydica, v.35, p. 165-175, 1990.

NAULT, L.R.; BRADFUTE, O.E. Corn stunt: involvement of a complex of leafhopper-borne pathogens. In: MARAMOROSCH, K.; HARRIS, K. (Ed.) Leafhopper vectors and plant disease agents. New York: Academic Press, 1979. cap.17, p.561-586.

NAULT, L.R.; DeLONG, D.M. Evidence for co-evolution of leafhoppers in the genus Dalbulus (Cicadellidae: Homoptera) with maize and its ancestors. Annals of the Entomological Society of America, v.73, p.349-353, 1980.

NAULT, L.R.; MADDEN, L.V. Ecological strategies of Dalbulus leafhoppers. Ecological Entomology, v.10, p.57-63, 1985.

OLIVEIRA, C.M. Variações morfológicas entre populações de Dalbulus maidis (DeLong \& Wolcott, 1923) (Hemiptera, Cicadellidae) de algumas localidades do Brasil. Piracicaba, 1996. 69p. Dissertação (Mestrado) - Escola Superior de Agricultura "Luiz de Queiroz", Universidade de São Paulo.

OLIVEIRA, E.; WAQUIL, J.M.; PINTO, N.F.J.A. Doenças causadas por patógenos transmitidos por insetos: complexo enfezamento/mosaico. In: SEMINÁRIO SOBRE A CULTURA DO MILHO "SAFRINHA", 4., Assis, 1997. Anais. Assis: IAC; CDV, 1997. p.87-94. 
OLIVEIRA, E.; WAQUIL, J.M.; FERNANDES, F.T.; PAIVA, E.; RESENDE, R.O.; KITAJIMA, E.W. Doenças do enfezamento na cultura do milho no Brasil Central - safra 94/95. Fitopatologia Brasileira, v.20, p.283, 1995.

OLIVEIRA, E.; WAQUIL, J.M.; FERNANDES, F.T.; PAIVA, E.; RESENDE, R.O.; KITAJIMA, E.W. "Enfezamento pálido" e "enfezamento vermelho" na cultura do milho no Brasil Central. Fitopatologia Brasileira, v.23, n.1, p.45-47, 1998.

POWER, A.G. Influence of plant spacing and nitrogen fertilization in maize on Dalbulus maidis (Homoptera: Cicadellidae), vector of corn stunt. Environmental Entomology, v.18, n.3, p.494-498, 1989.

SCOTT, G.E.; ROSENKRANZ, E.E.; NELSON, L.R. Yield loss of corn due to corn stunt disease complex. Agronomy Journal, v.69, p. 92-94, 1977.

SHURTLEFF, M.C. Compendium of corn diseases. 2.ed. St. Paul American Phytopathological Society, 1986. 105p.

SILVA, H.P. Incidência de doenças füngicas na "safrinha". In: SEMINÁRIO SOBRE A CULTURA DO MILHO "SAFRINHA", 4., Assis, 1997. Anais. Assis: IAC; CDV, 1997. p.81-86.

SILVA, H.P.; PEREIRA, O.A.P.; MACHADO, J.; MONELLI, V.L. Identificação e controle das doenças de milho. Informativo Coopercitrus, v.6, n.61, p. 18-24, 1991. 
TSAI, J.H.; FALK, B.W. Tropical maize pathogens and their associated insect vectors. In: HARRIS, F.K. (Ed.) Advances in disease vector research. New York: Springer-Verlag, 1988. v.5, cap.8, p.117-201.

WAQUIL, J.M. Amostragem e abundância de cigarrinhas e danos de Dalbulus maidis (DeLong \& Wolcott) (Homoptera: Cicadellidae) em plântulas de milho. Anais da Sociedade Entomológica do Brasil, v.26, n.1, p.27-33, 1997.

WAQUIL, J.M.; FERNANDES, F.T. Flutuação populacional da cigarrinha do milho, Dalbulus maidis, no CNPMS. In: CONGRESSO NACIONAL DE MILHO E SORGO, 19., Porto Alegre, 1992. Resumos. Porto Alegre: SAA; SCT; ABMS; EMATER/RS; EMBRAPA, CNPMS; CIENTEC, 1992. p.68.

WAQUIL, J.M.; VIANA, P.A. Eficiência do tratamento do solo ou da semente no controle de Dalbulus maidis em milho. In: CONGRESSO NACIONAL DE MILHO E SORGO, 21., Londrina, 1996. Resumos. Londrina: ABMS; IAPAR, 1996. p.319.

WAQUIL, J.M.; OLIVEIRA, E.; FERNANDES, F.T. Incidência de Dalbulus maidis e enfezamento pálido no Ensaio Nacional de milho safrinha. In: CONGRESSO NACIONAL DE MILHO E SORGO, 21., Londrina, 1996. Resumos. Londrina: ABMS; IAPAR, 1996. p.318.

WAQUIL, J.M.; OLIVEIRA, E.; PINTO, N.F.J.A. Incidência de cigarrinha, enfezamento e viroses em milho. In: SEMINÁRIO SOBRE A CULTURA DO MILHO "SAFRINHA, 4., Assis, 1997. Anais. Assis: IAC; CDV, 1997. p.101-105. 
WAQUIL, J.M.; VIANA, P.A.; CRUZ, I.; SANTOS, J.P. Aspectos da biologia da cigarrinha-do-milho, Dalbulus maidis (DeLong \& Wolcott) (Hemiptera: Cicadellidae). Anais da Sociedade Entomológica do Brasil, v.28, n.3, p.413-420, 1999. 